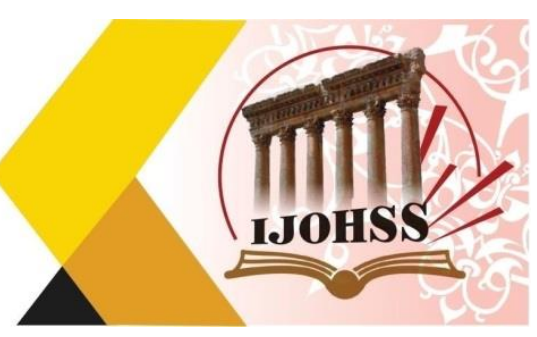

\title{
الشيخ فضل الله النوري ودوره الفكري والسياسي في انتفاضة التبغ والتباك في ايران (1890-1892)
}

$$
\text { جامعة ذي قار جبر علية الاداب }
$$

\author{
أ.م.د. حيلر عبد العالي جبر \\ جامعة ذي قار - كلية الآداب جاب جالبر \\ العراق
}

الماخص

شهد تاريخ إيران الحديث و المعاصر ، بروز كثير من الثخصيات الدينية العلمائية ، التي أدت ادواراً سياسية و اجتماعية وثقافية مهمة تصدر واجهة الأحداث آنذاك ـ يعد الثيخ فضل الله النوري إحدى هذهِ الثخصيات إن لم

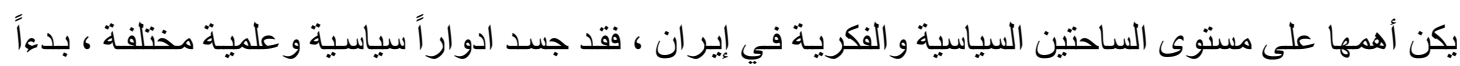
بانتفاضـة التبـغ ( التنباك) 1891- 1892 التي كـان فيها الصـوت المجلجل للميرزا الثشير ازي صـاحب الفتوى الثهيرة ، ومحط أنظار العلماء و الجماهير ـ إذ عمل على تنظيم المجتمع العلمائي ، وتنوير أفكار العوام ونضـج الإدر اك و الإحساس العقيدي ، الى الحد الذي يرى فيه بعض المؤرخين إنه السبب وراء إصدار الفتوى (تحريم التنبالك ) .

الكلمات المفتاحية: الثيخ فضل الله النوري، انتفاضة التبغ و التنباك، اير ان. 


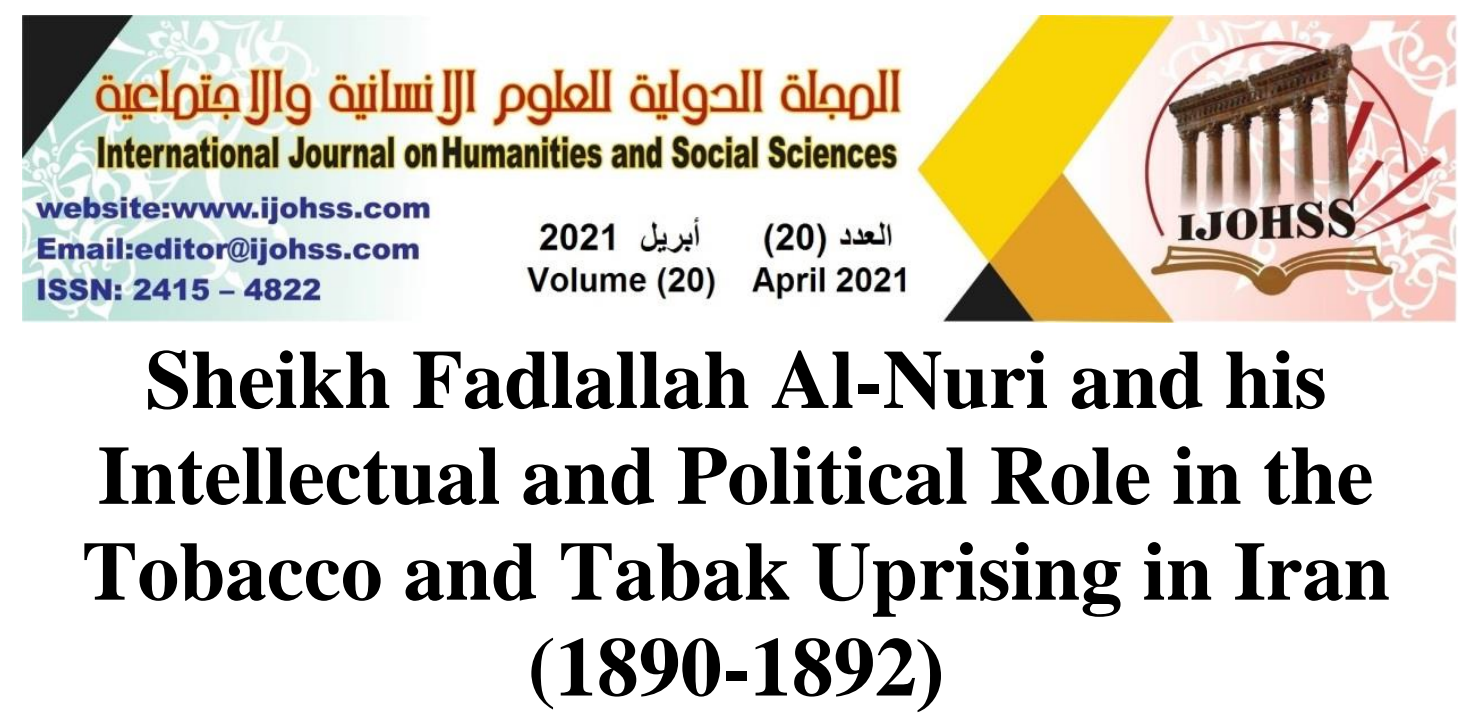

\author{
Assist. Prof. Dr. Haider Abdelali Jaber \\ Dhi Qar University - Faculty of Arts \\ Iraq
}

\author{
Assist. Lect. Haider Jabr Ali \\ Dhi Qar University - Faculty of Arts \\ Iraq
}

\begin{abstract}
Iran's modern and contemporary history has witnessed the emergence of many scholarly religious figures who played important political, social and cultural roles that were at the forefront of events at the time. Sheikh Fadlallah al-Nuri is one of these personalities, if not the most important on the level of the political and intellectual arenas in Iran. And the masses. As he worked to organize the scholarly community and enlighten people to the extent that some historians see him as the reason behind the issuance of the fatwa (the prohibition of abuse).

It turned out that Sheikh Fadlallah al-Nuri had a prominent role in the tobacco uprising, and it was the first successful political experiment that he fought and commissioned by the Mujaddid al-Mujaddid Mirza al-Shirazi, and it became clear that his goal to move to Iran was purely political, by conveying everything that happens of deterioration in Iran's general conditions to the religious and social leadership And the political establishment in Samarra, and to make it a picture due to the weakness of the means of communication, after the governmental apparatus persisted in his despotism by making Iran a commodity exposed to foreigners, and the Sheikh also succeeded in his first uprising by highlighting the importance and strength of the religious establishment because of the tools it possesses by which it controlled the rhythm of the Iranian people with an Islamic orientation, as well. On his contribution to revitalizing the protest movement in exercising its role in the future to influence the course of Iranian governments, and the Sheikh took the initiative to strike foreign interests by showing the danger of the tobacco privilege and forbidden because of its great strategic importance for the acquisition in the Iranian state, but rather considered it a form Clear and direct colonization of the capabilities of the people.
\end{abstract}

Keywords: Sheikh Fadlallah Al-Nouri, The Tobacco and Tabak Uprising, Iran. 


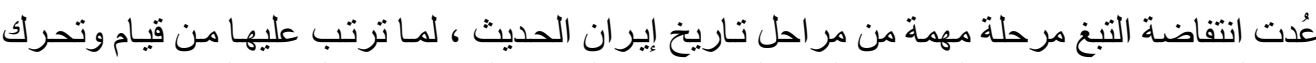

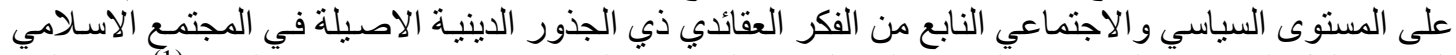

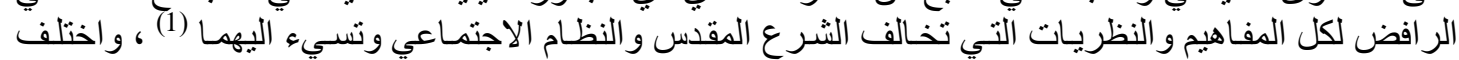

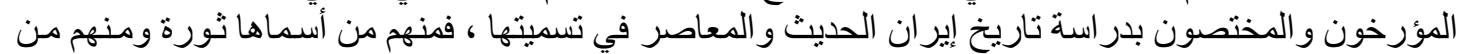

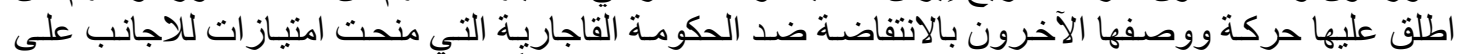

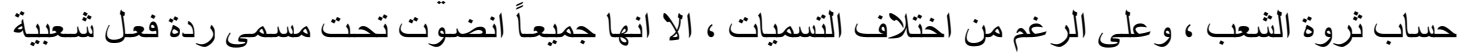

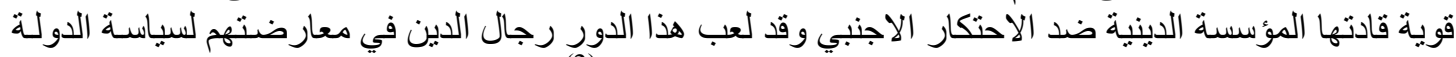

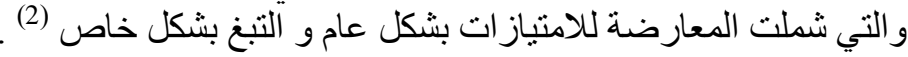

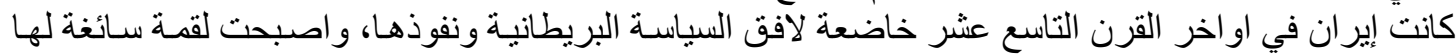

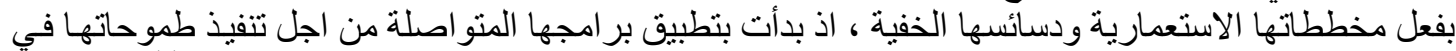

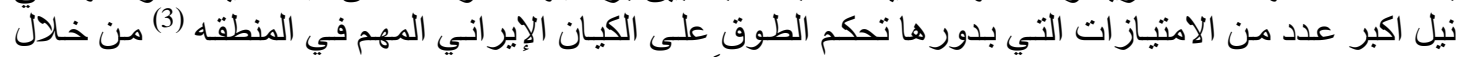

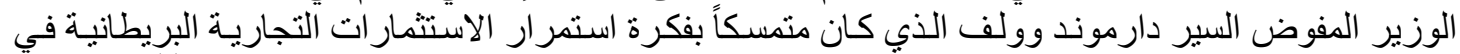

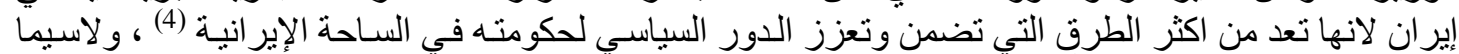

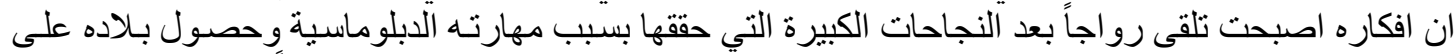

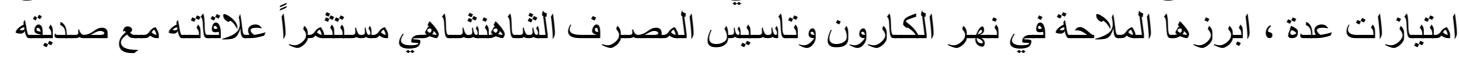

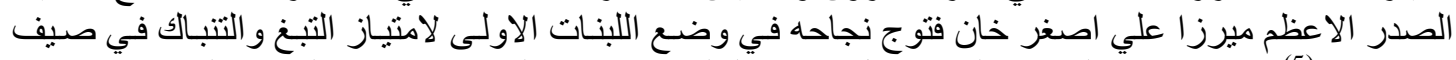

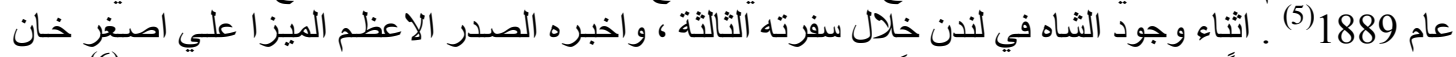

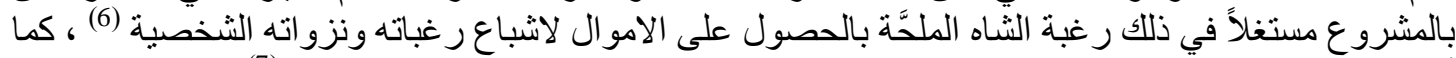

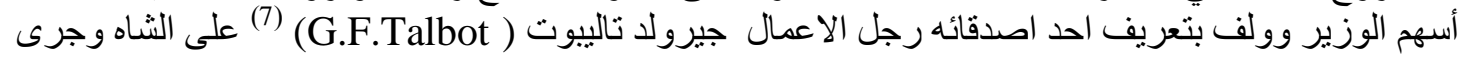

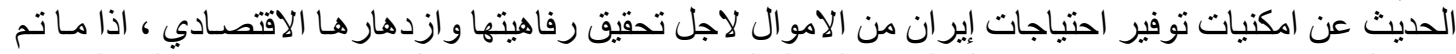

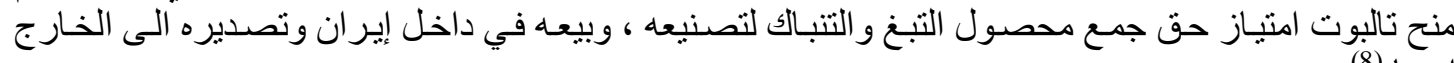
ايضا (8)

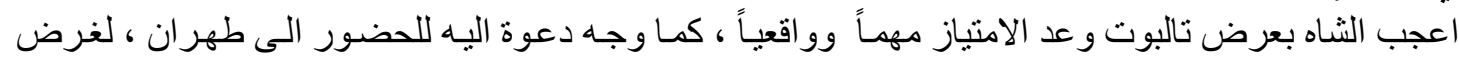

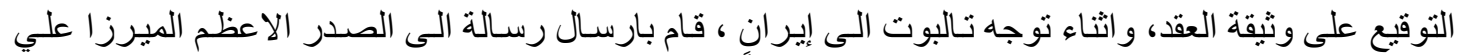

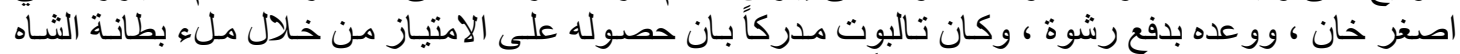

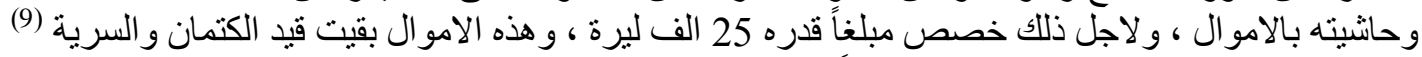

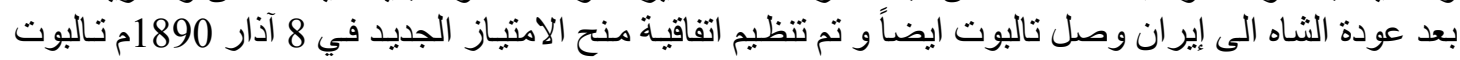

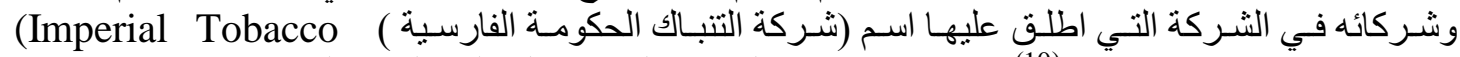

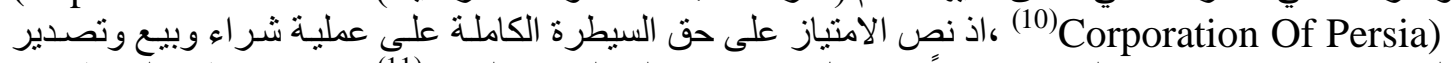

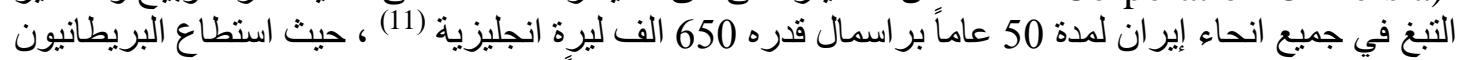

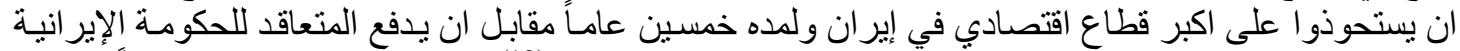

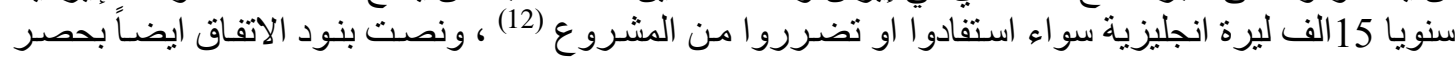

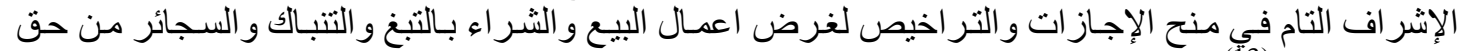

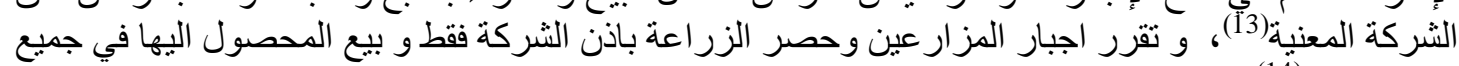

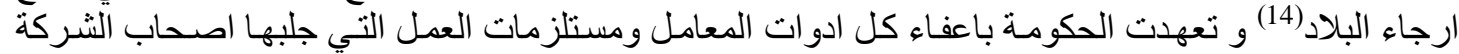

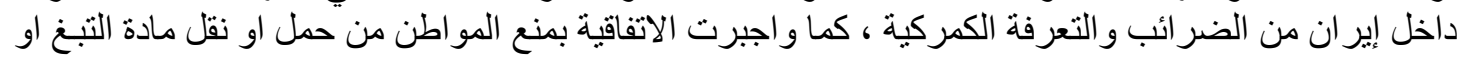

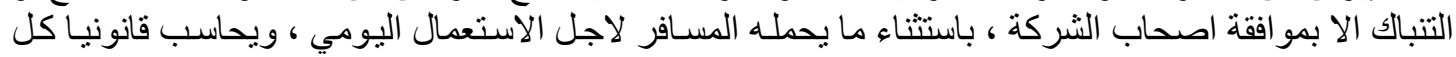

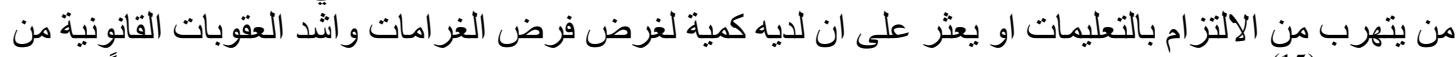

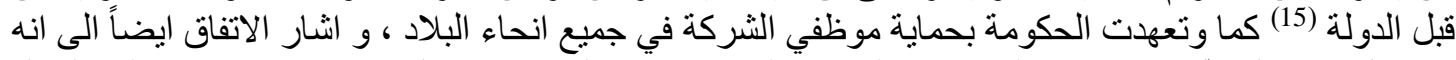

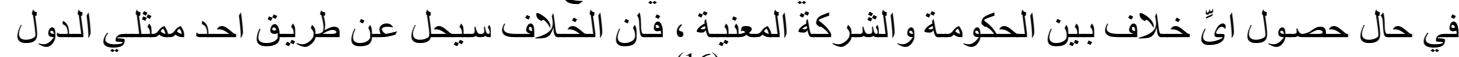

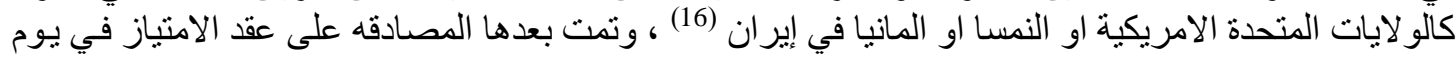

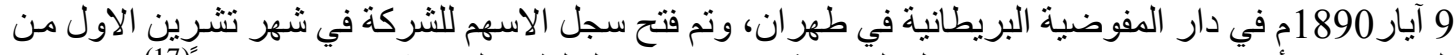

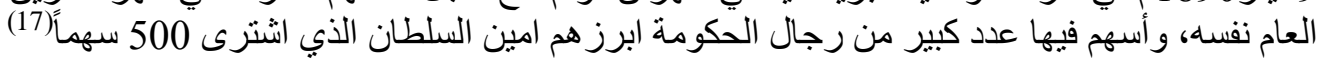




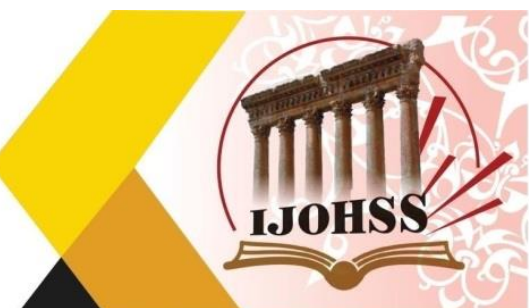

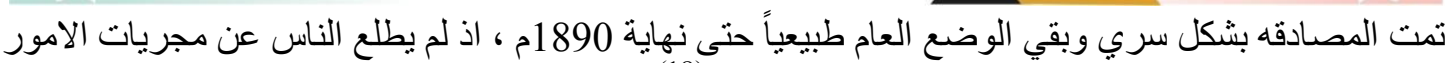

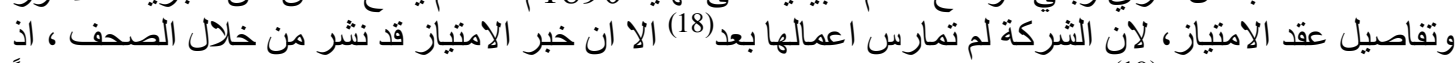

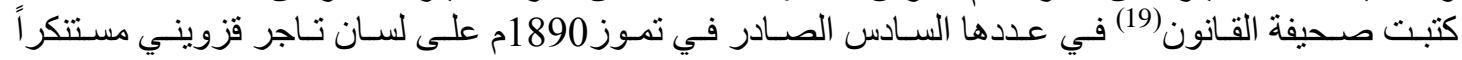

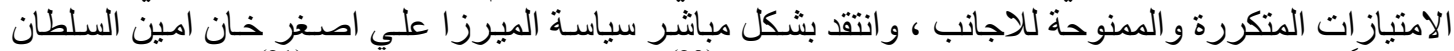

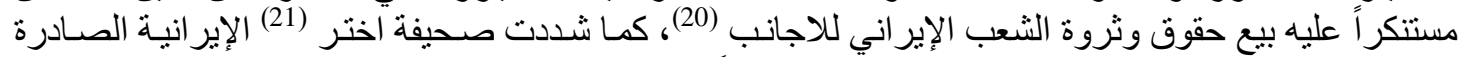

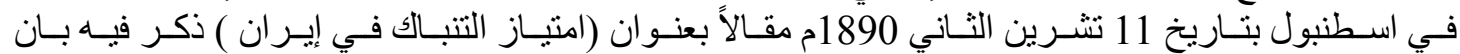

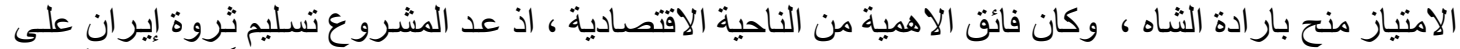

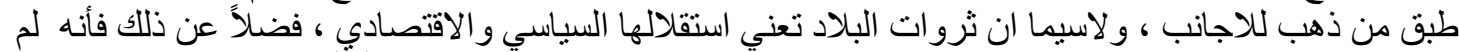

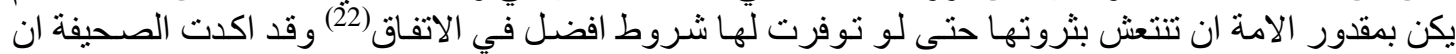

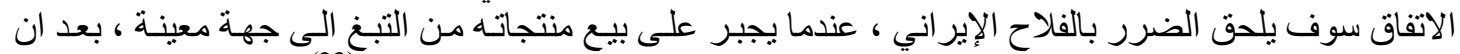

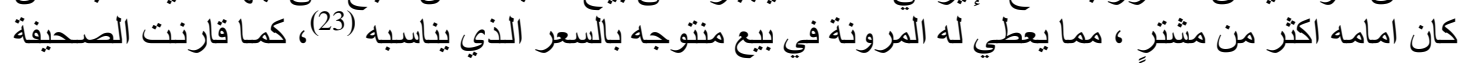

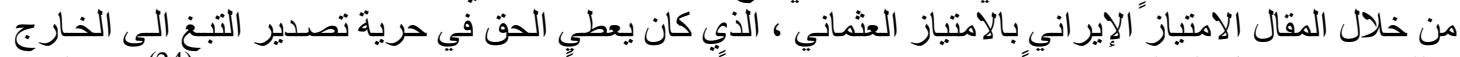

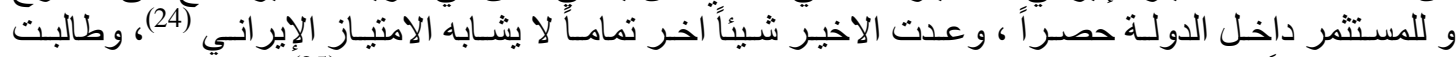

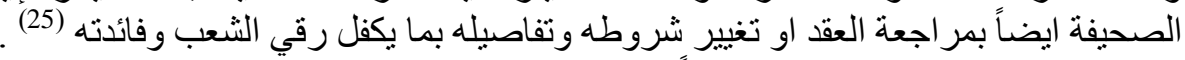

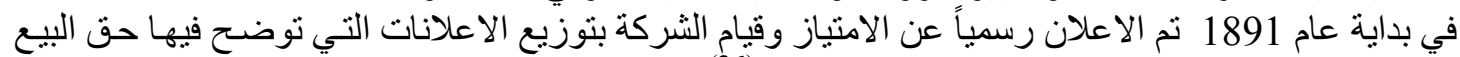

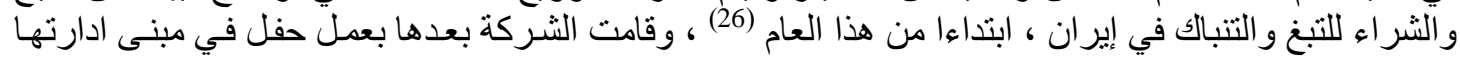

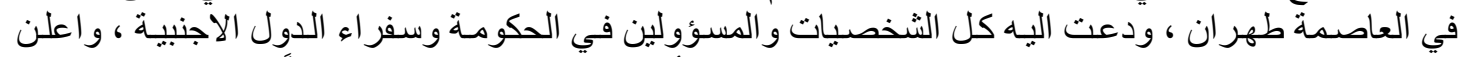

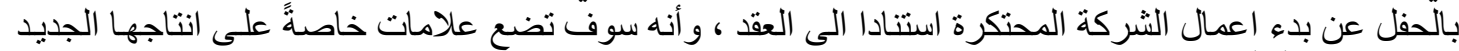

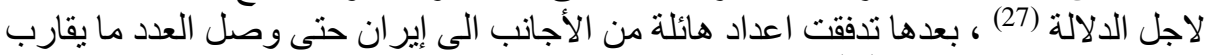

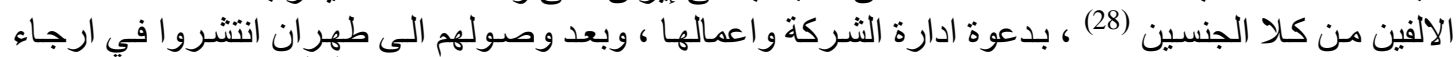

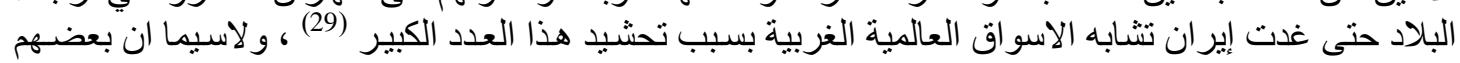

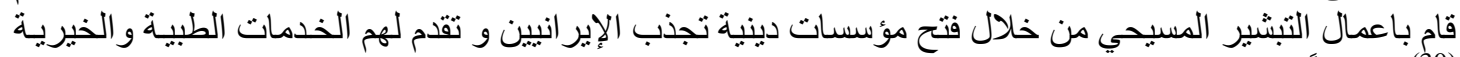

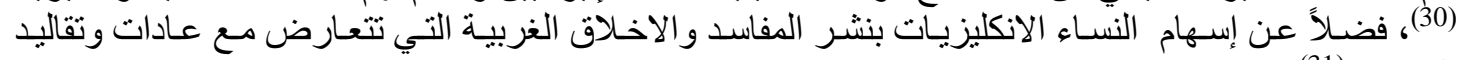

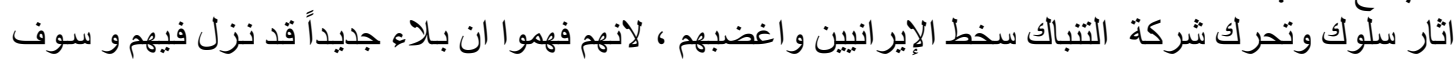

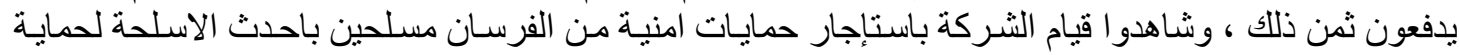

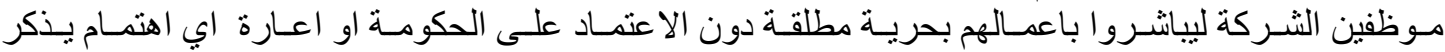

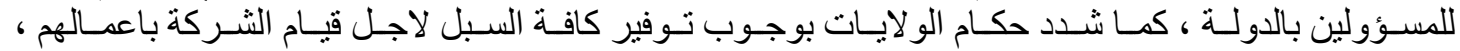

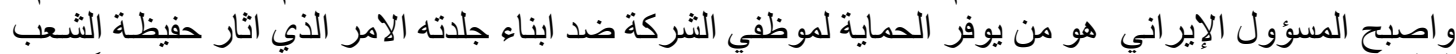

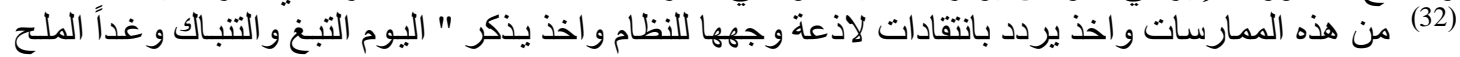

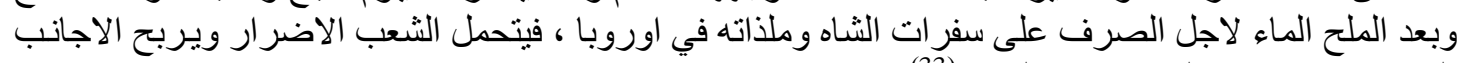

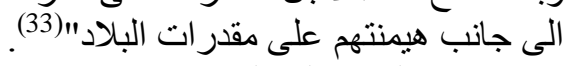

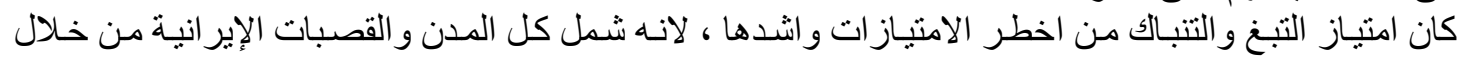

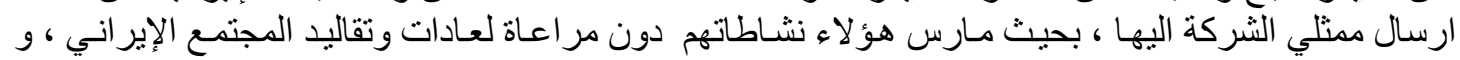

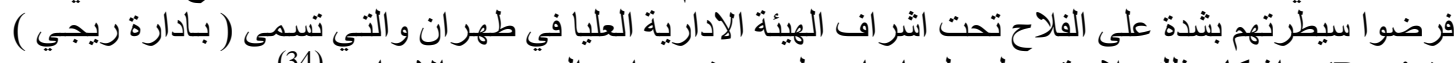

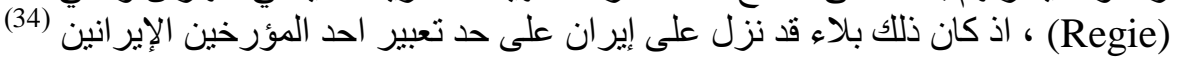

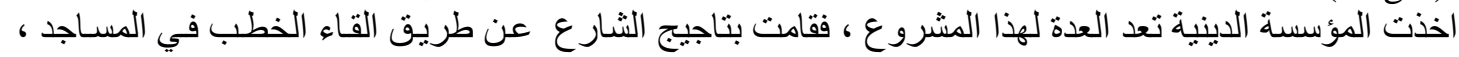

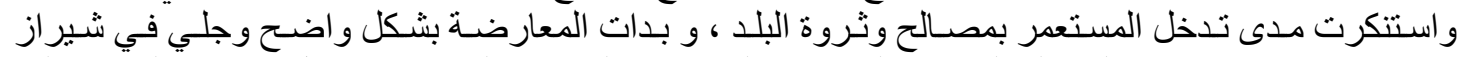

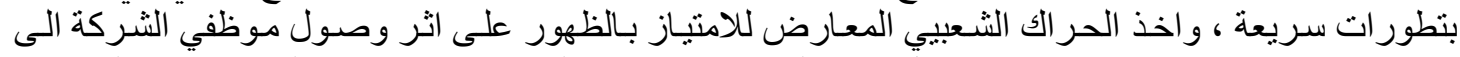

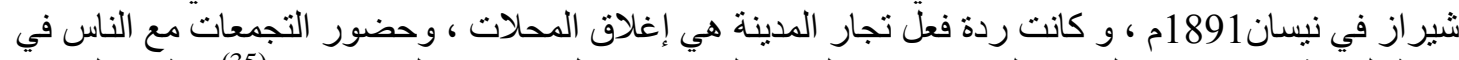

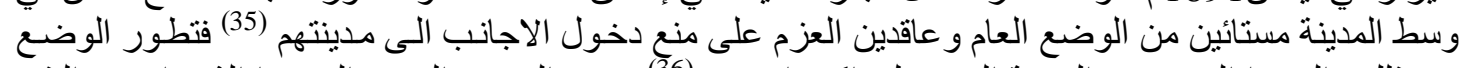

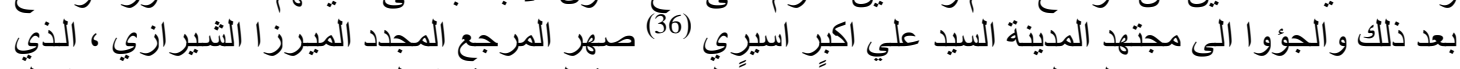

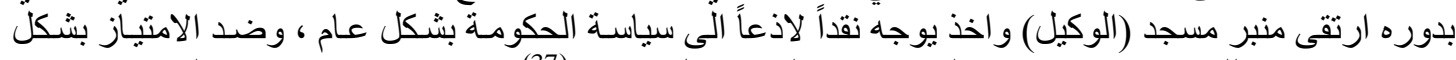

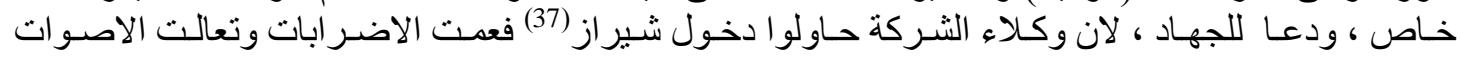




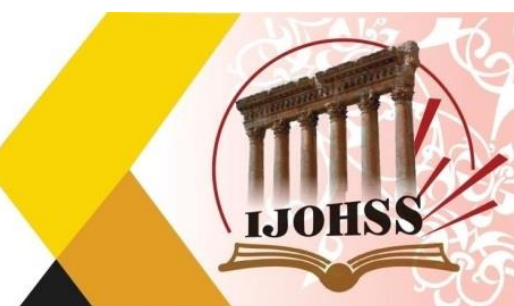

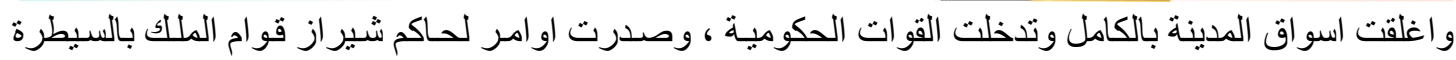

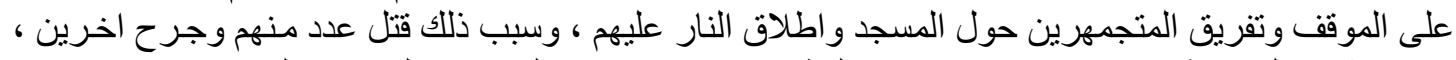

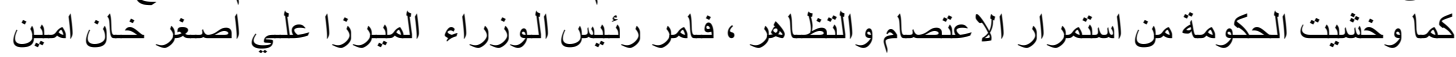

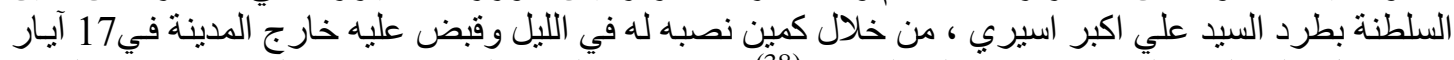

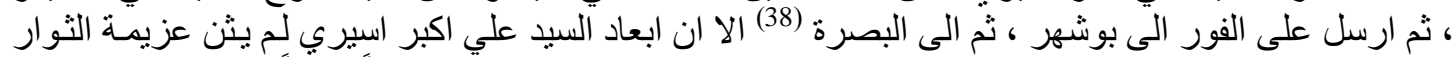

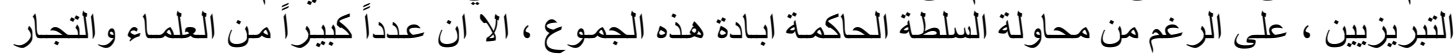

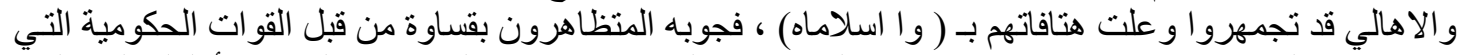

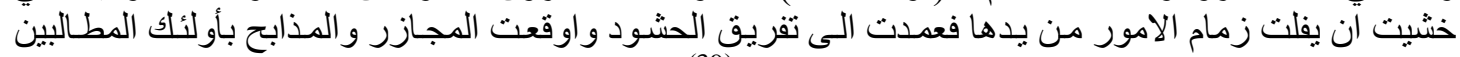

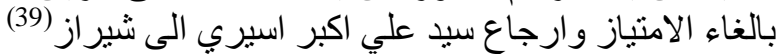

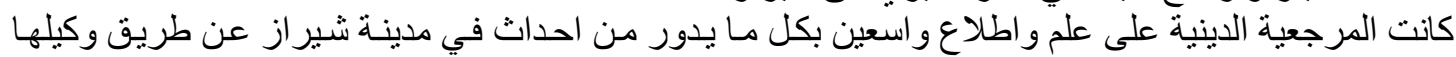

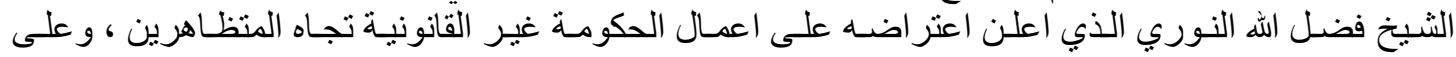

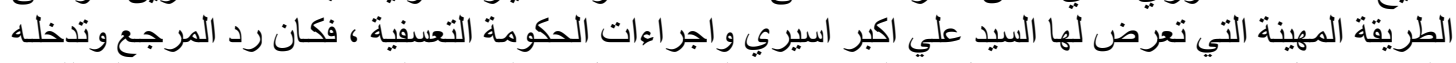

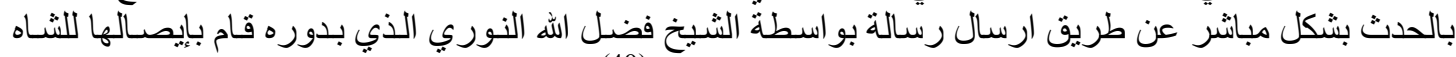
بو اسطة نجل الثاه كامير ان نائب السلطنة في 26 تموز

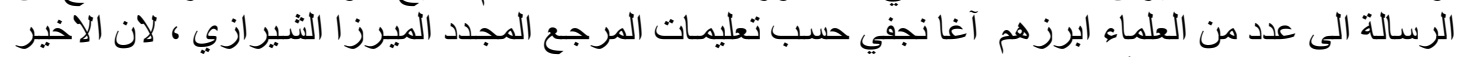

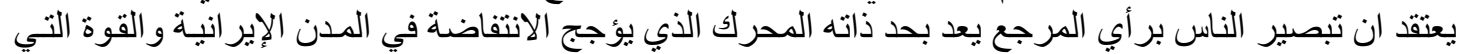

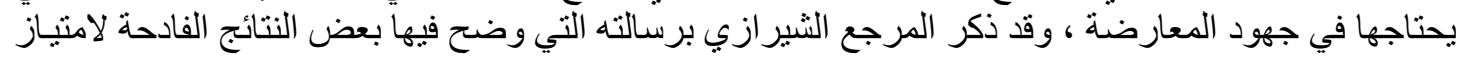

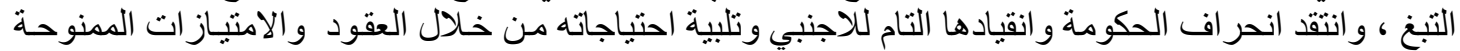

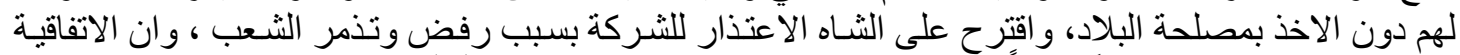

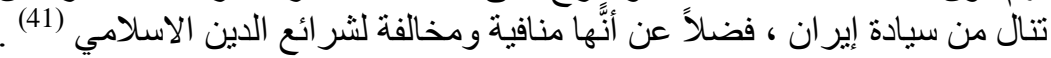

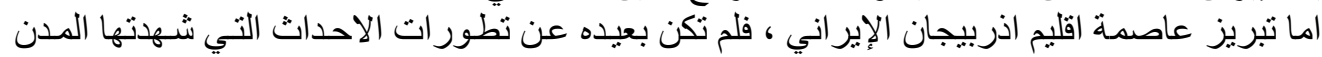

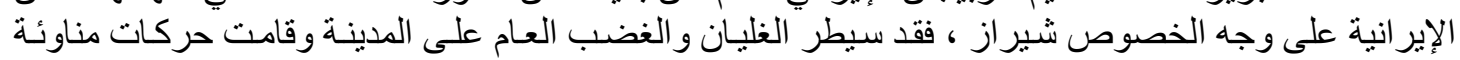

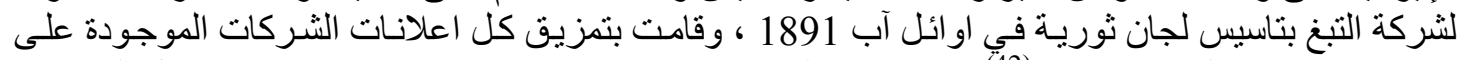

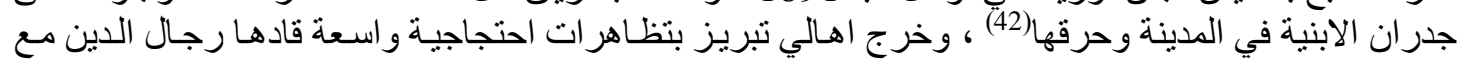

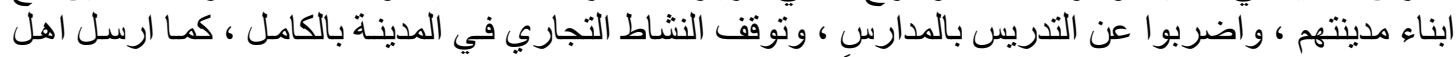

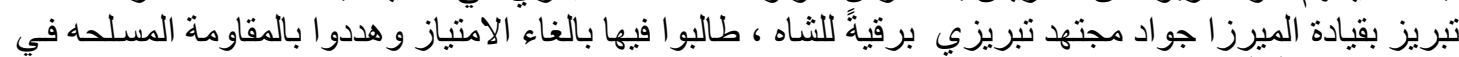

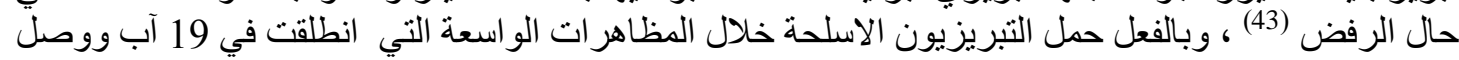

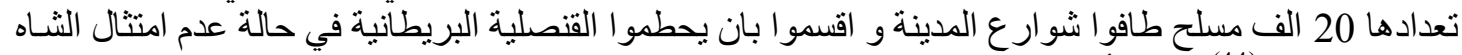

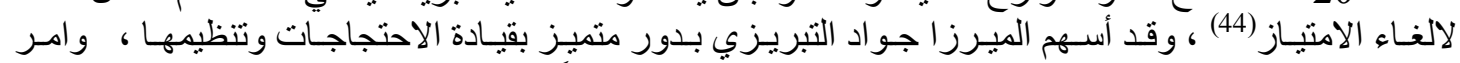

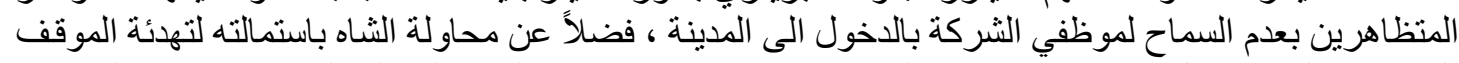

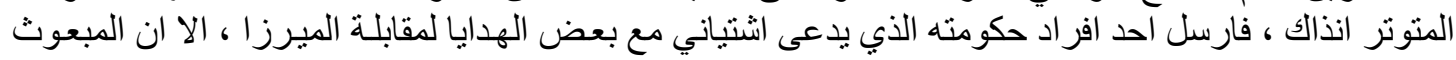

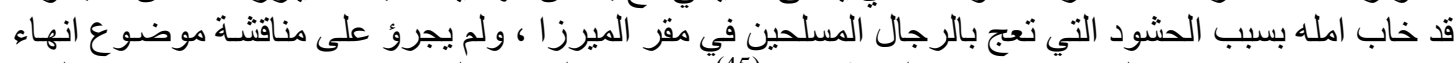

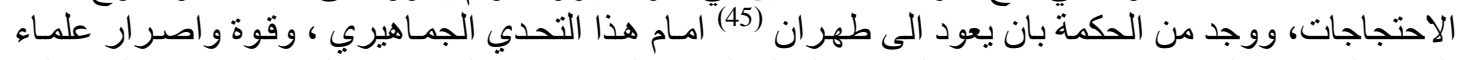

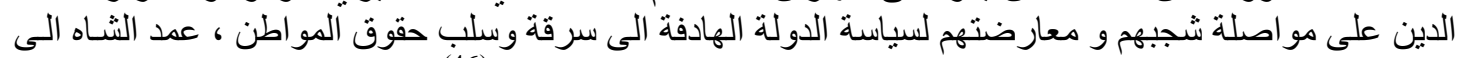

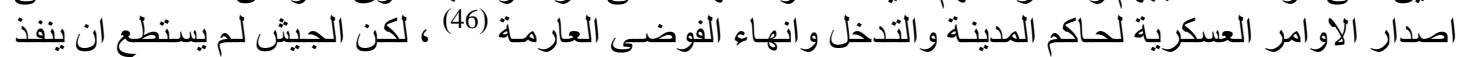

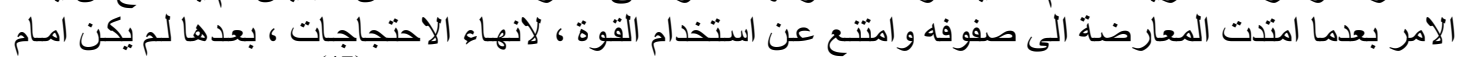

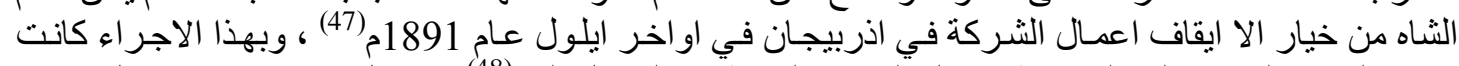

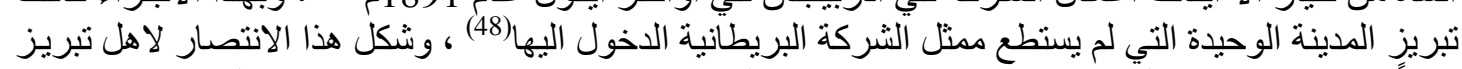

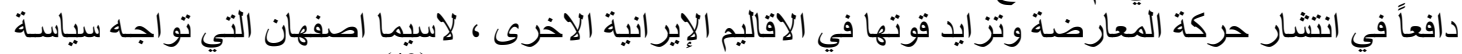

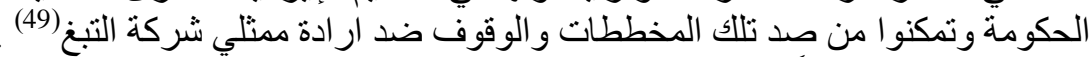

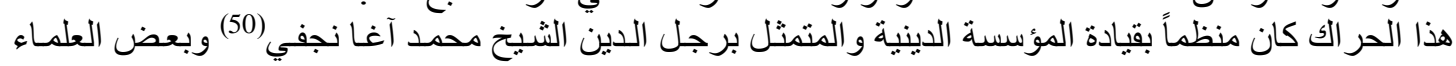

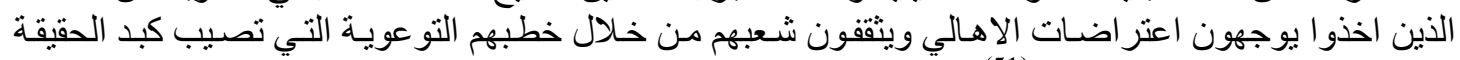

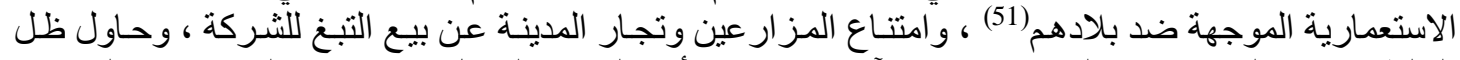

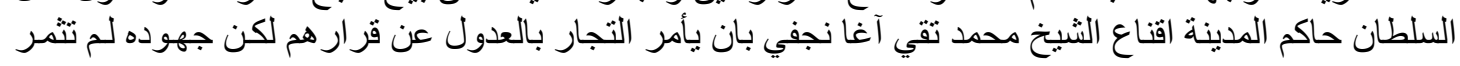




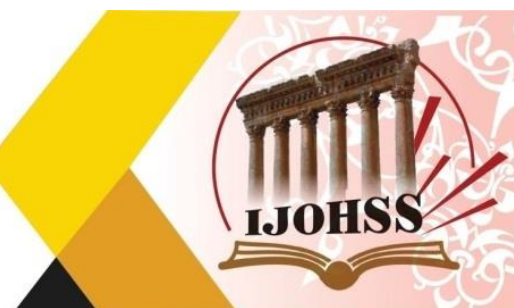

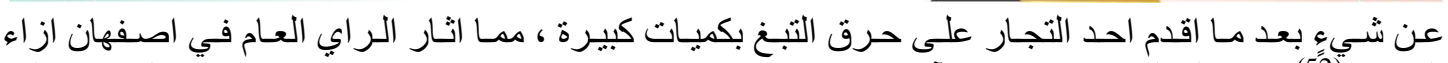

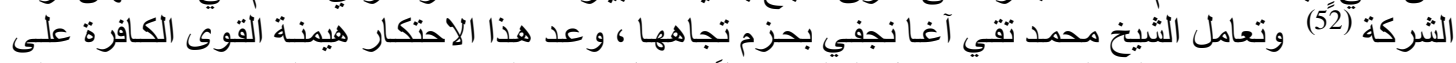

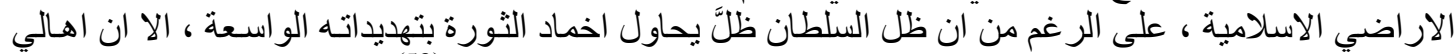

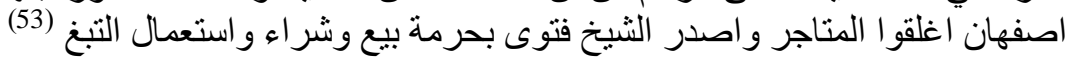

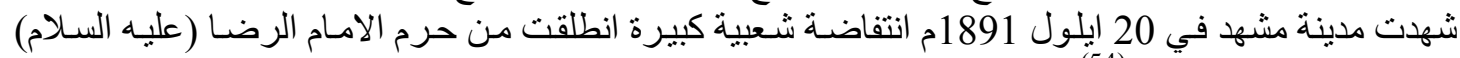

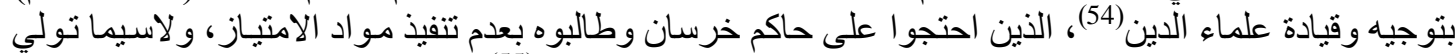

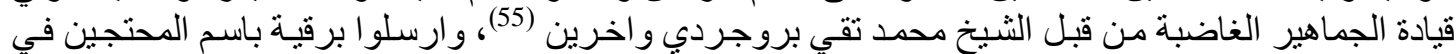

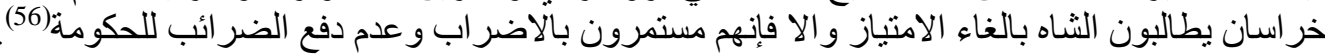

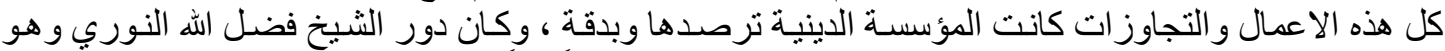

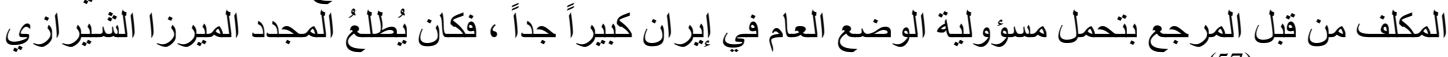

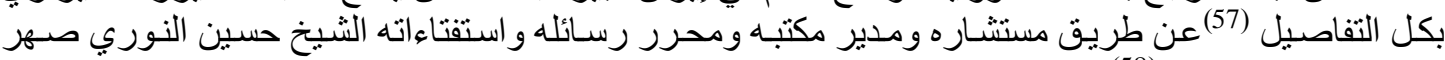

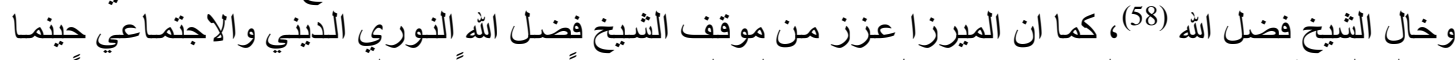

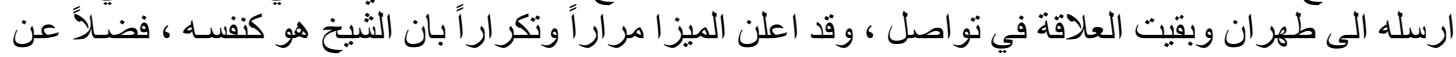

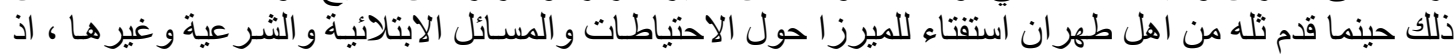

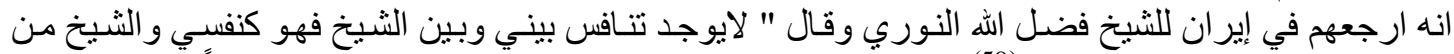

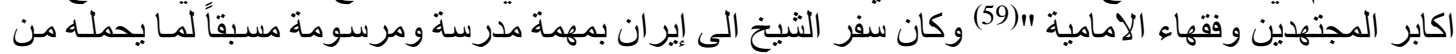

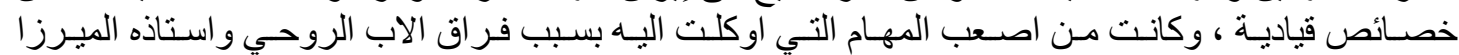

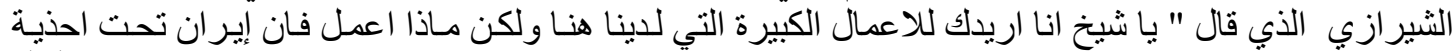

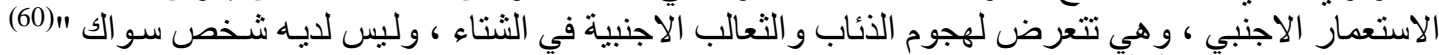

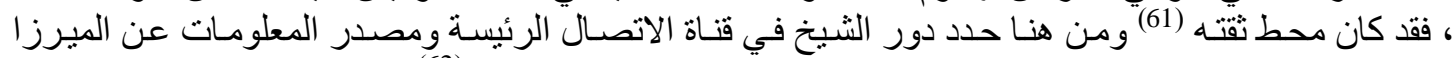

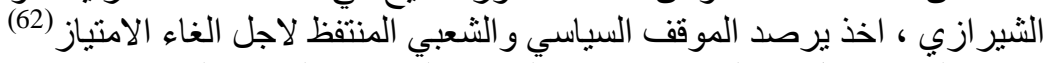

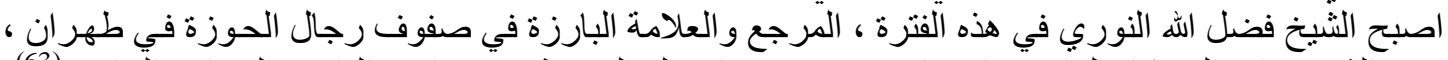

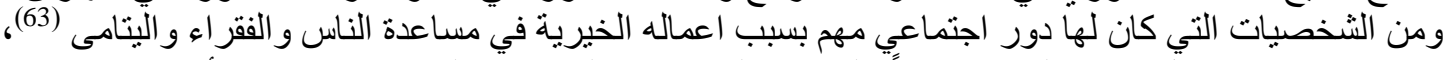

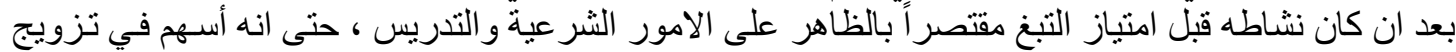

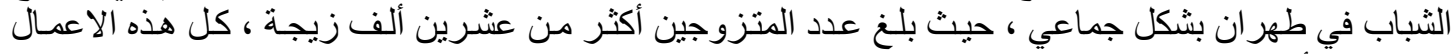

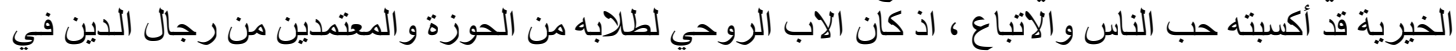

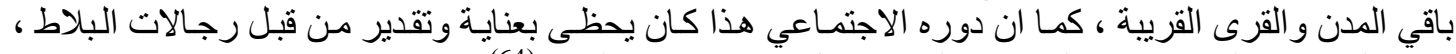

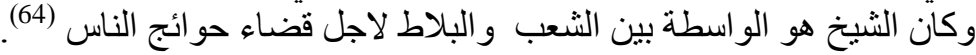

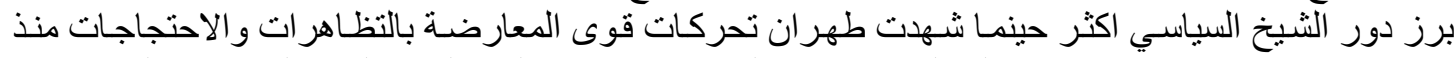

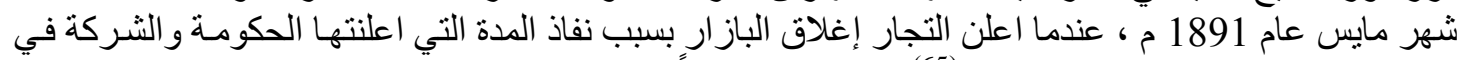

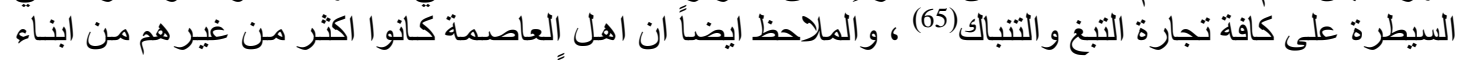

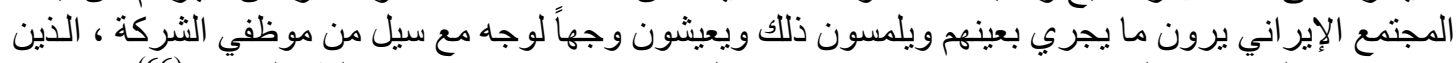

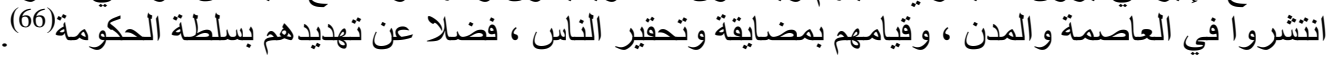

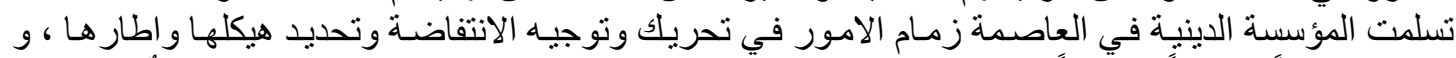

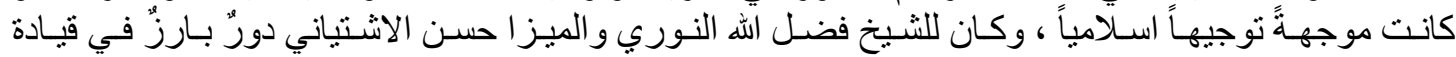

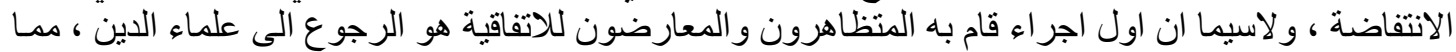

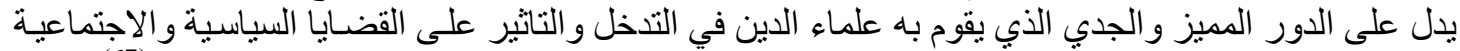

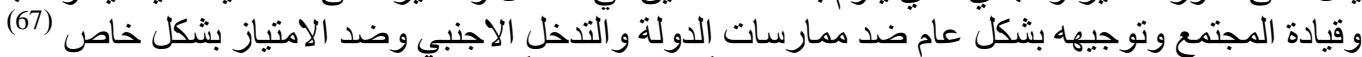

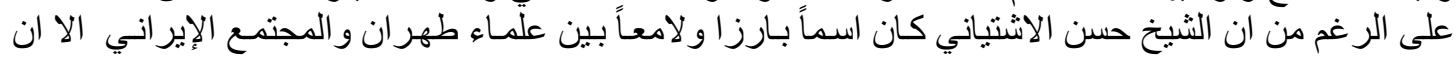

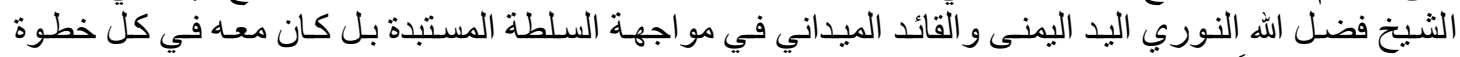

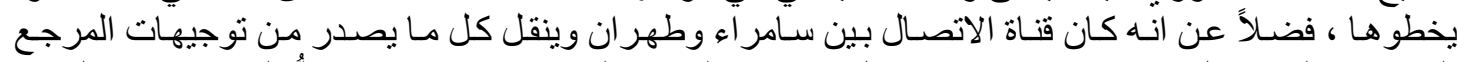

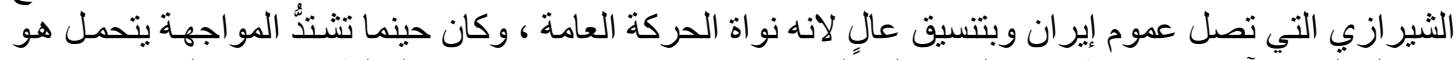

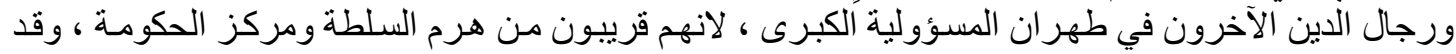
تكمن صعوبة هذا الدور في ان الثيخ يدير وينسق الحركة بين القين القيادة و القاعدة العامـة في المجتمع وفي وفي عموم 


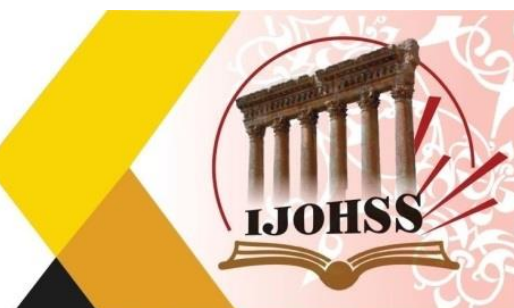

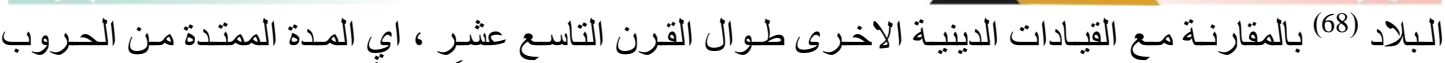

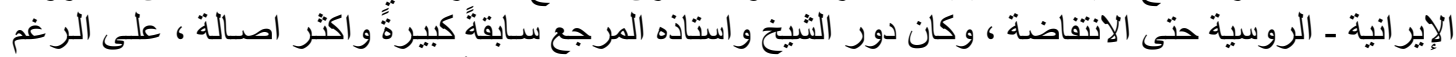

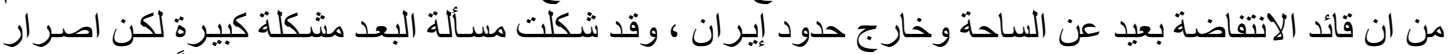

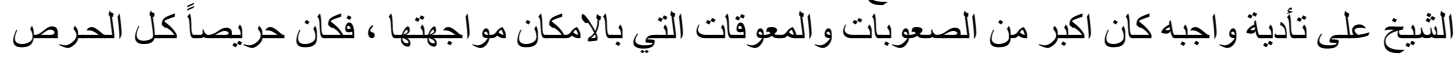

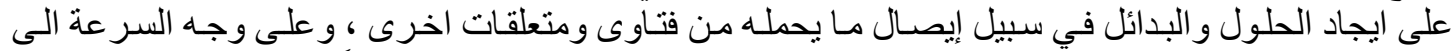

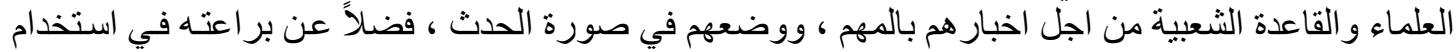

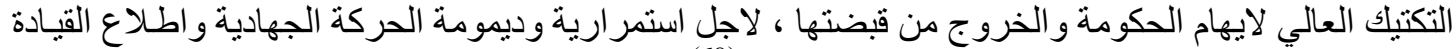

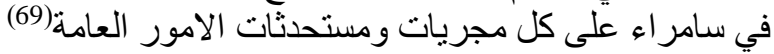

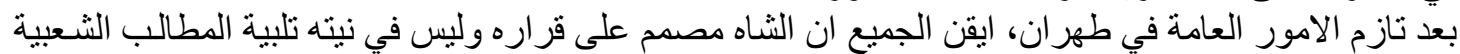

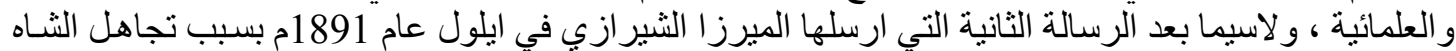

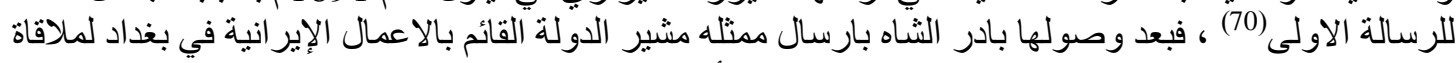

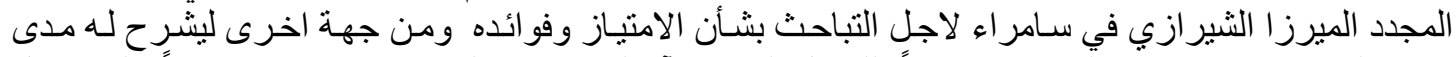

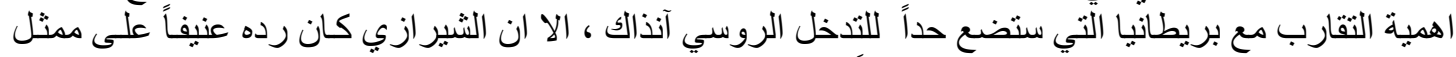

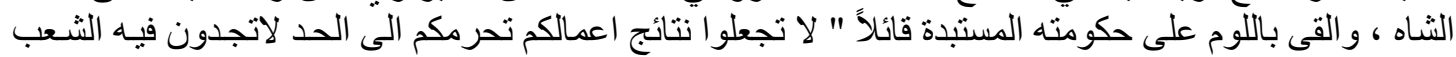

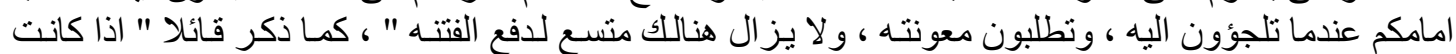

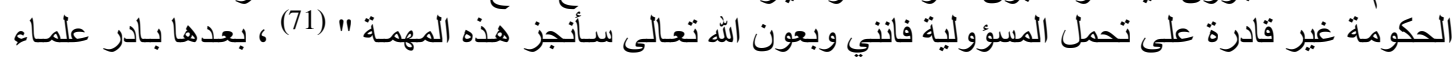

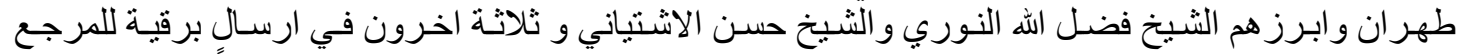

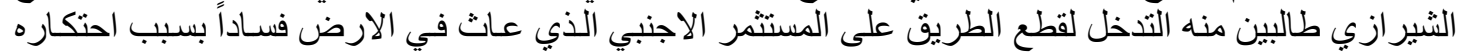

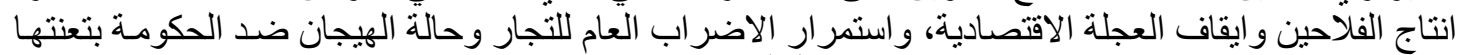

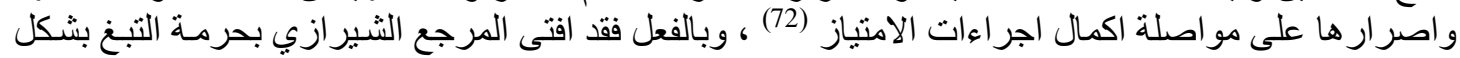

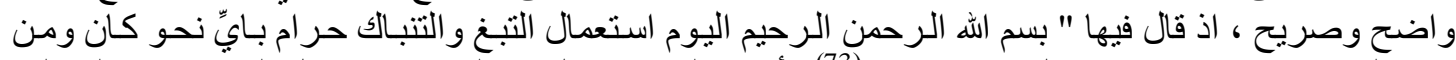

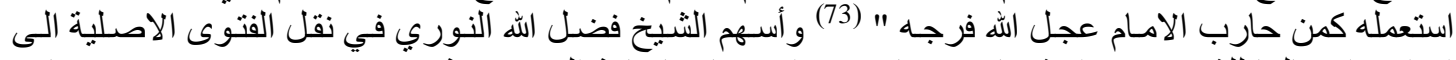

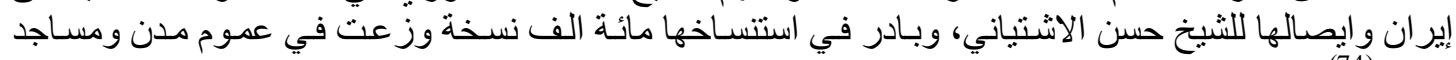
(74) إيران (74)

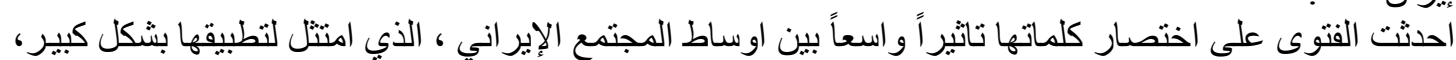

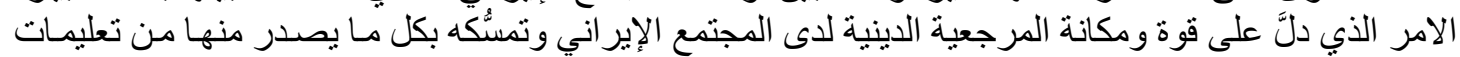

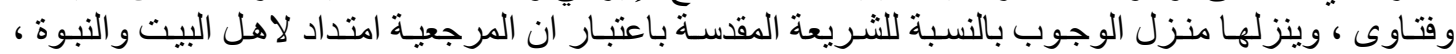

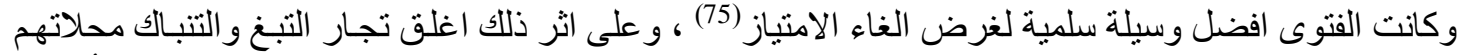

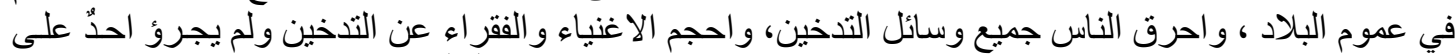

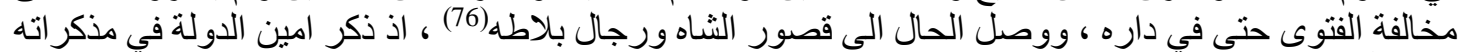

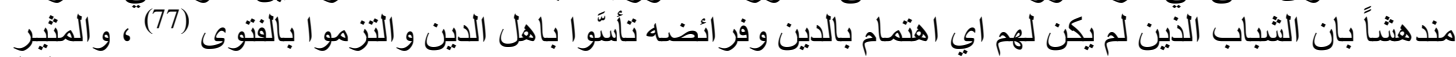

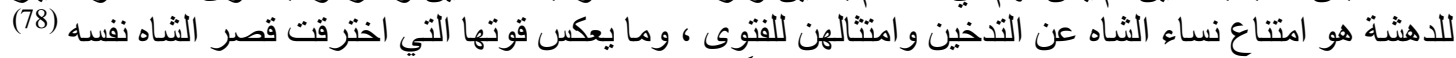

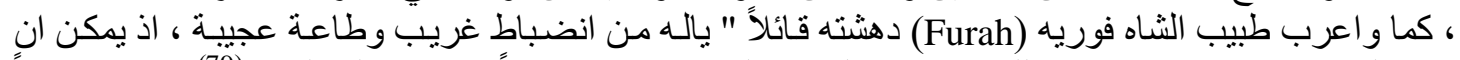

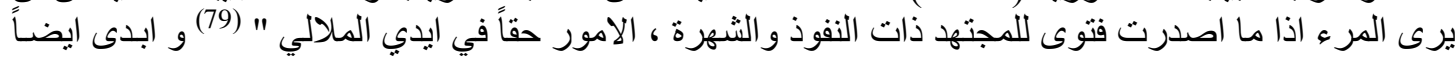

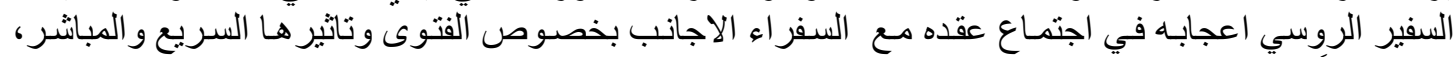

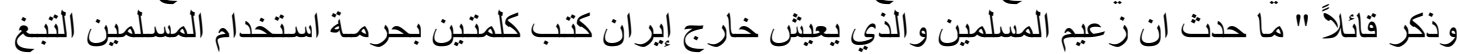

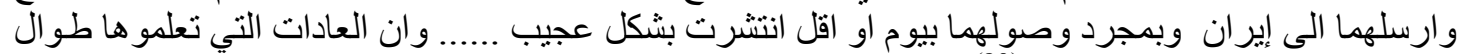

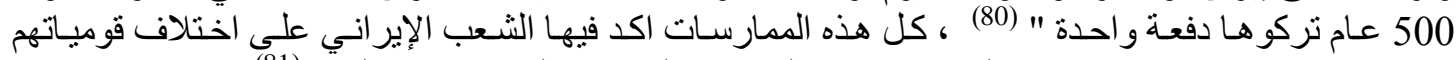

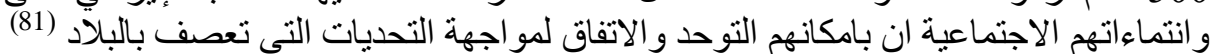

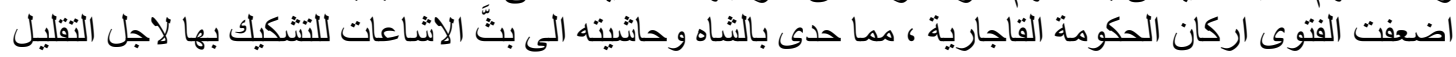

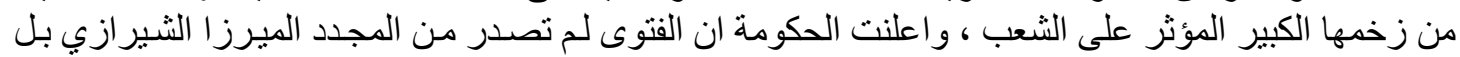

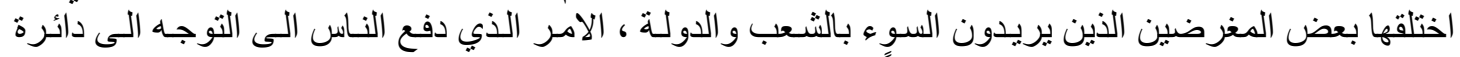

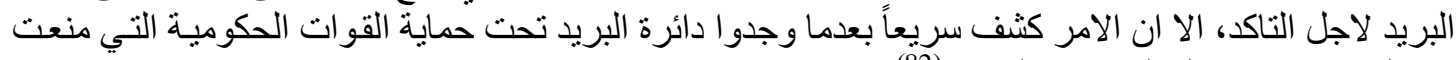

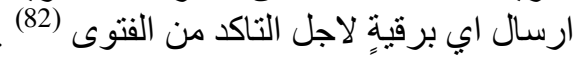




\section{Volume (20) April 2021}

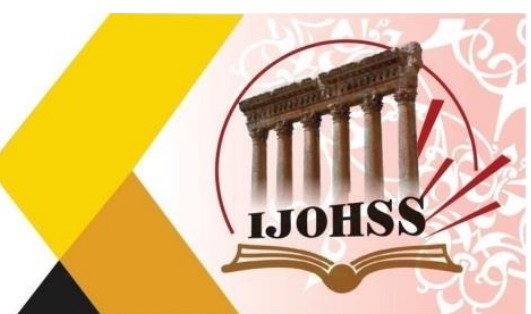

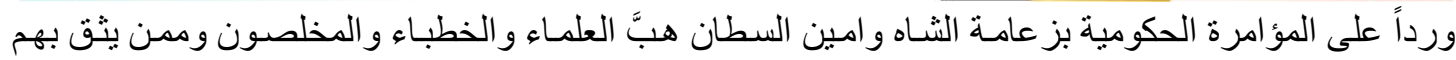

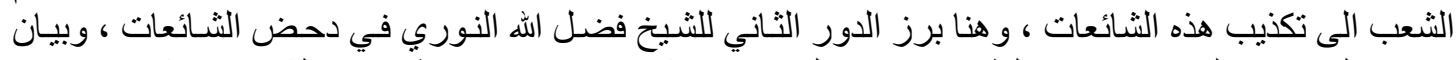

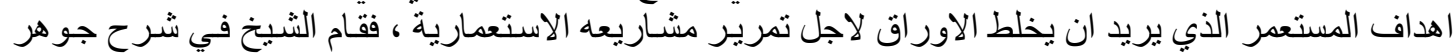

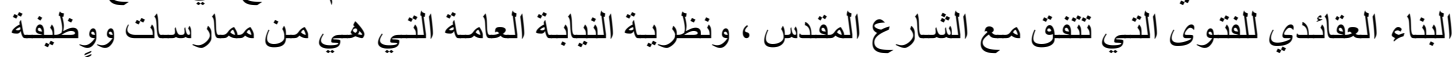

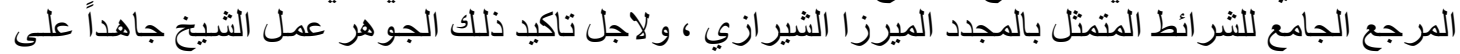

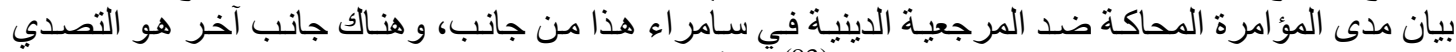

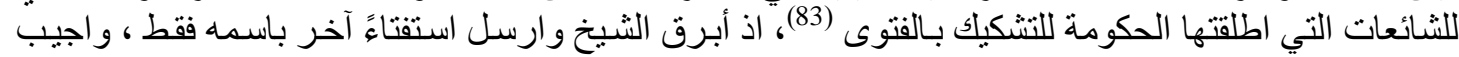

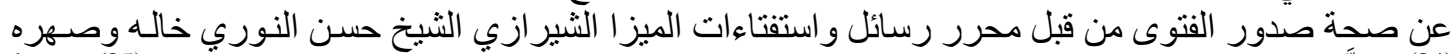

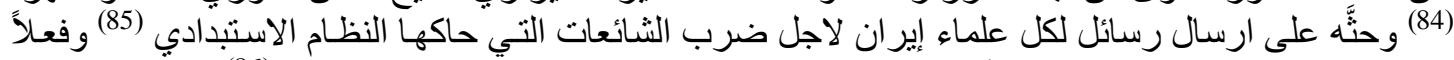

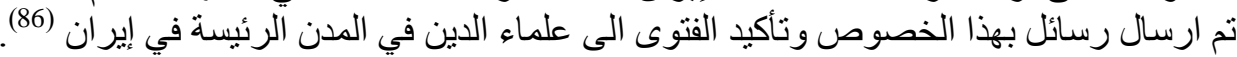

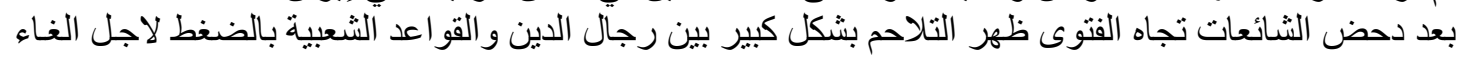

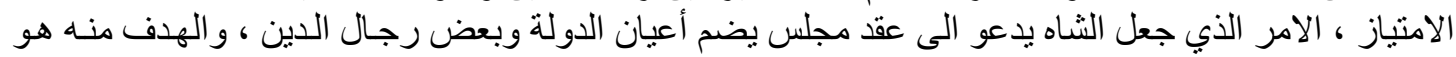

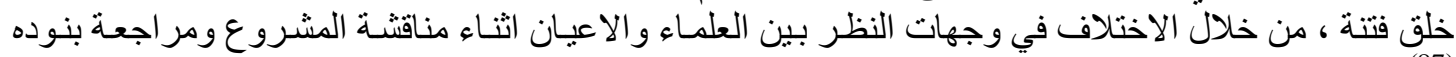

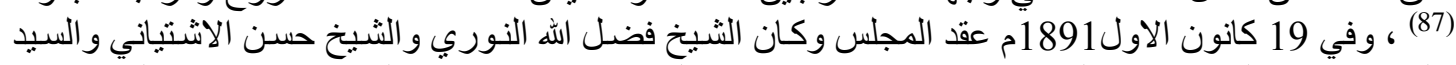

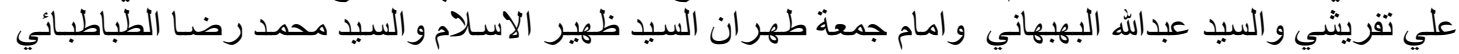

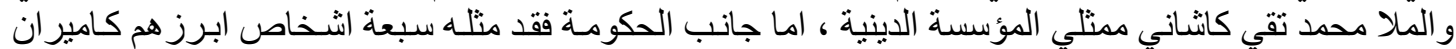

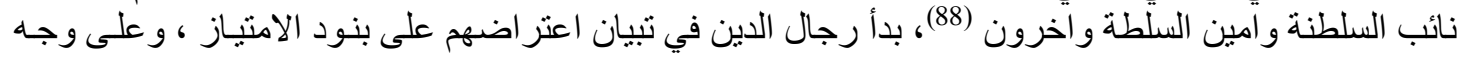

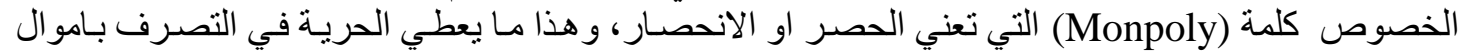

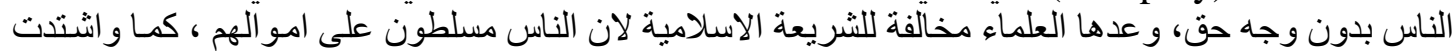

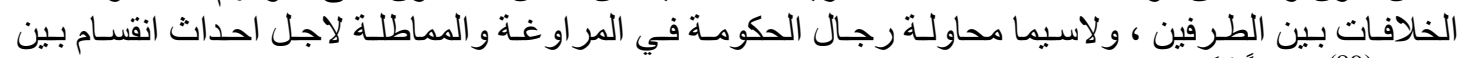

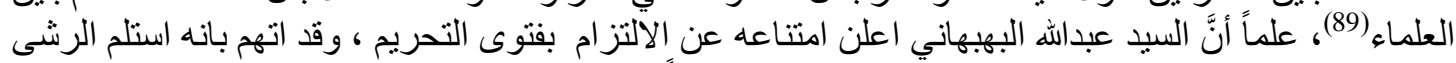

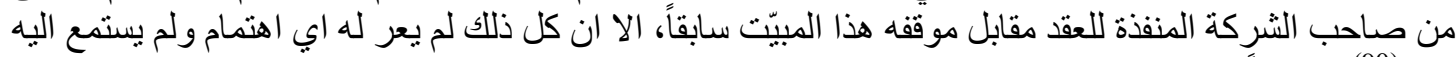

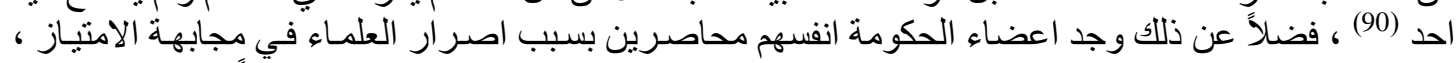

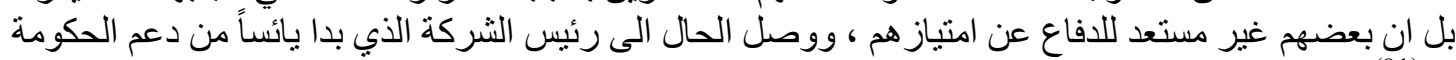

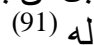

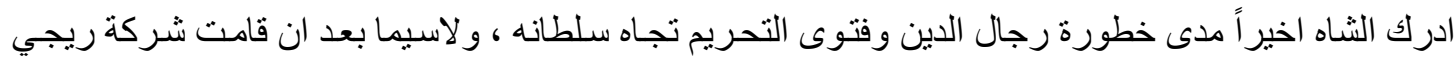

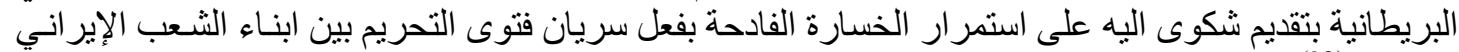

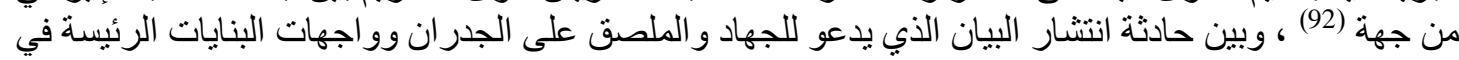

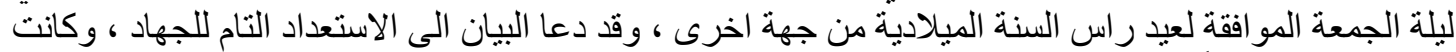

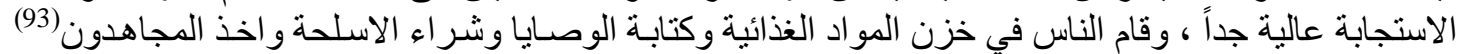

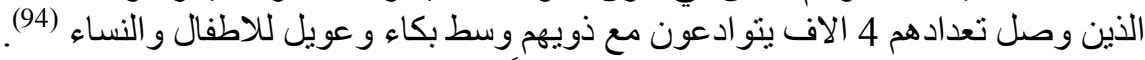

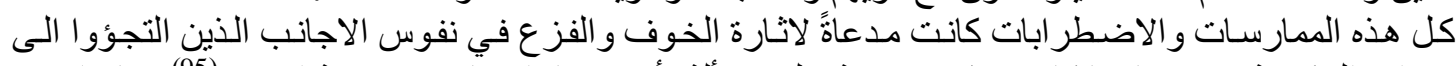

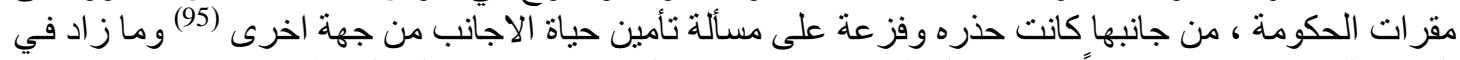

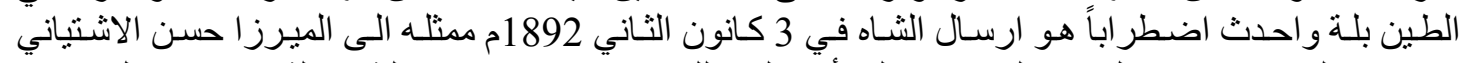

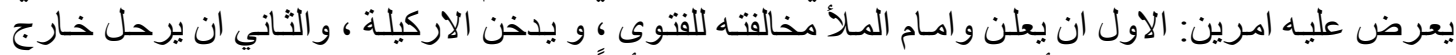

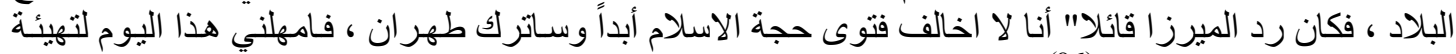

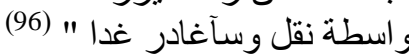

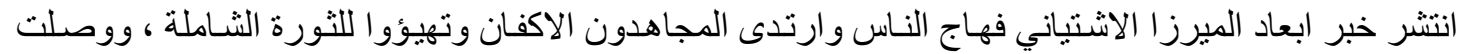

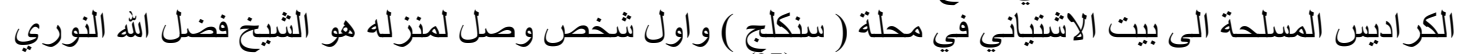

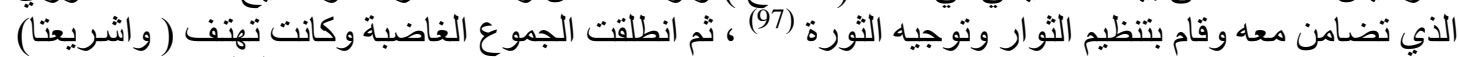

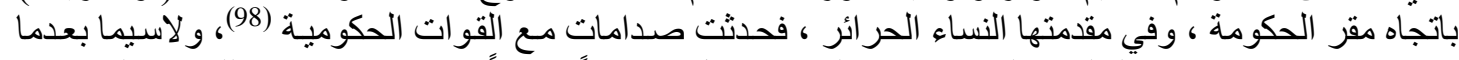

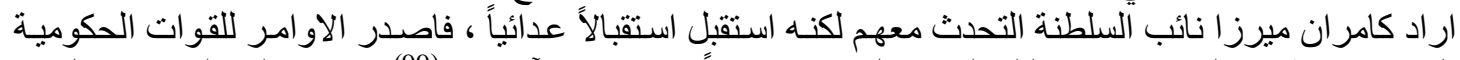

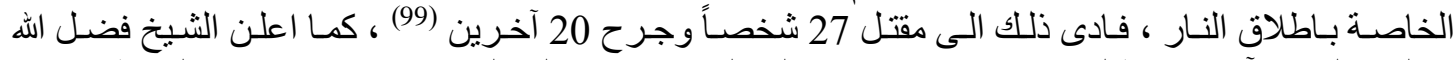

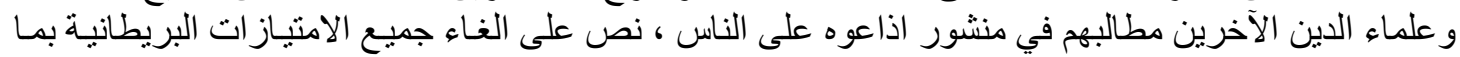




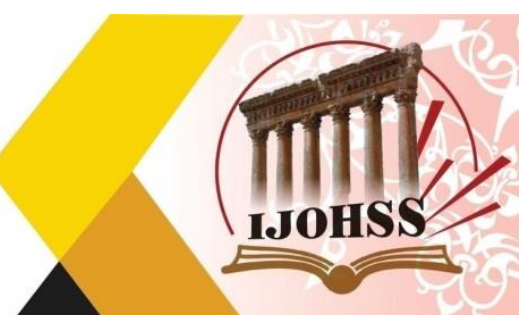

فيها الملاحة في نهر الكارون و المشـاريع الاخرى في بندر عباس وبوشهر على الخليج العربي ، وشددوا بل

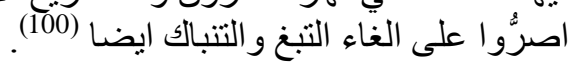

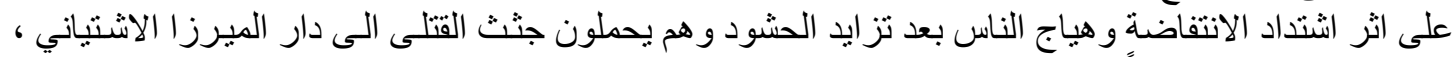

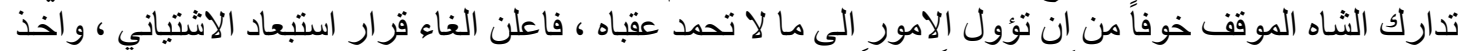

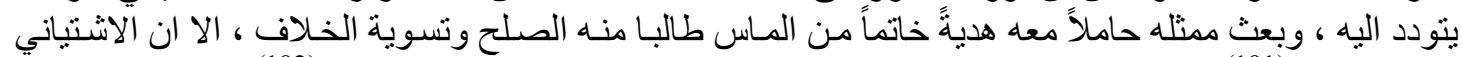

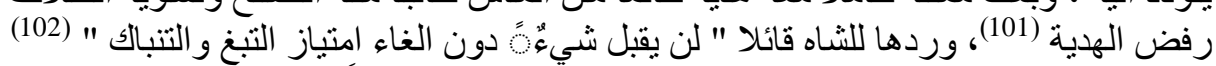

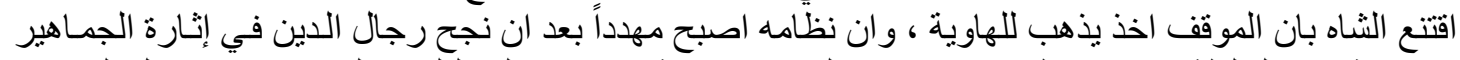

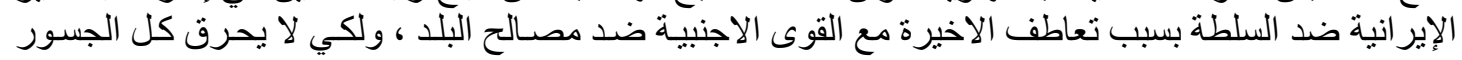

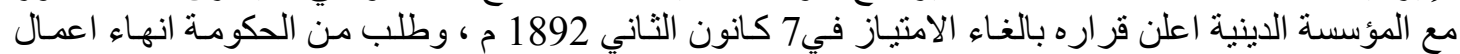

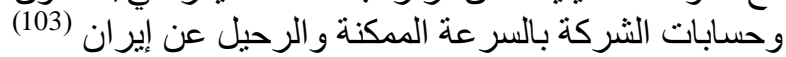

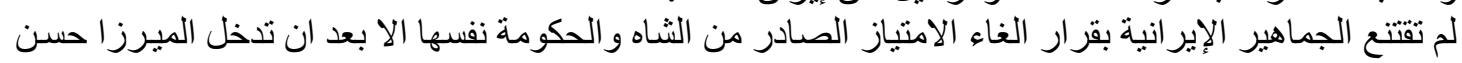

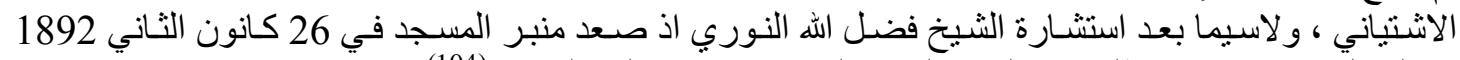

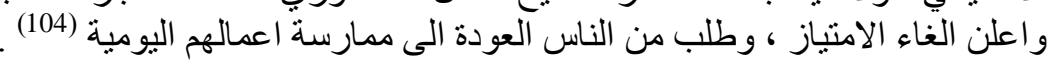

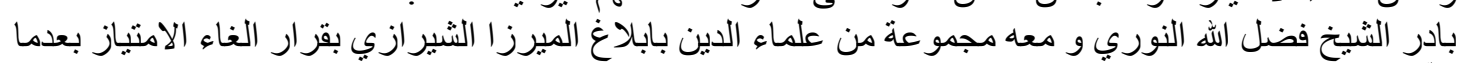

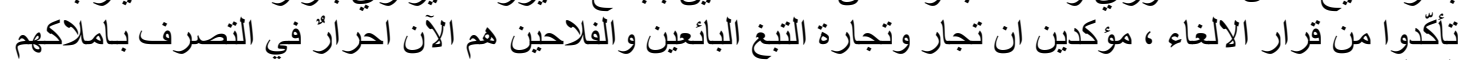

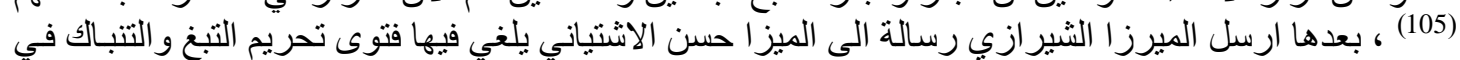
إيران (106).

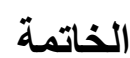

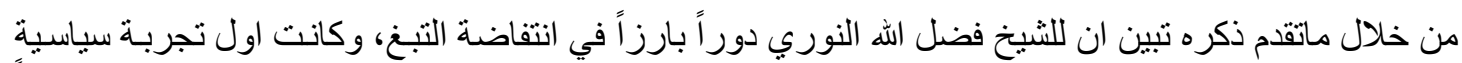

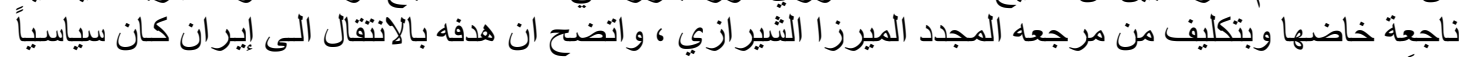

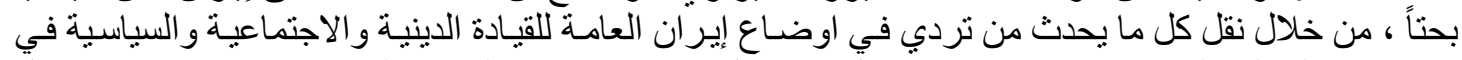

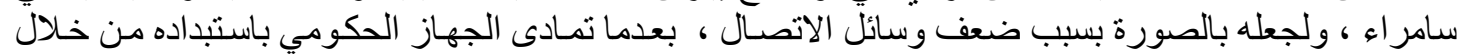

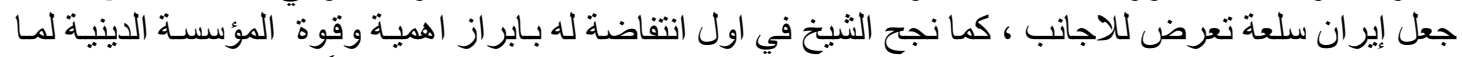

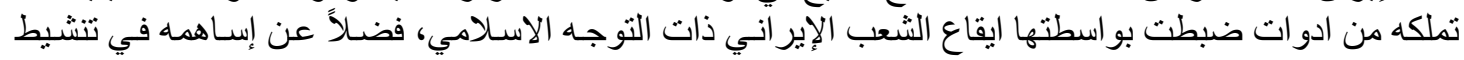

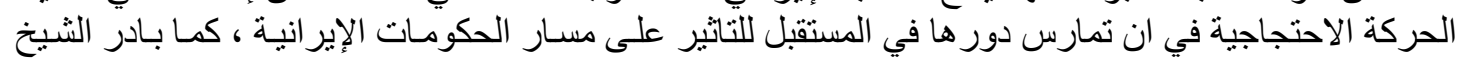

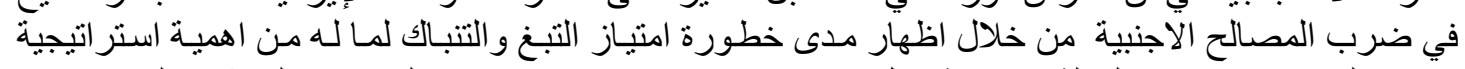

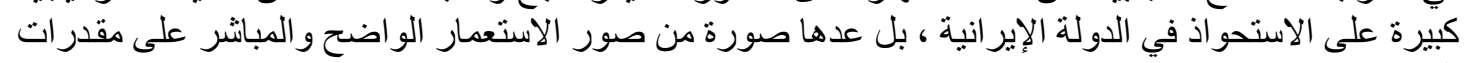

\section{هو ت مش البحث}

(1) مهذي ابو طالبى ، نقش نبابت فقها در نهضت تنباكو به عنو ان يكى از ريشه هاى تاريخى انقلاب اسلامى ، مطالعات

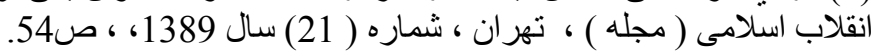

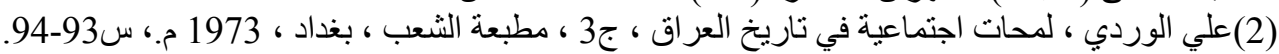

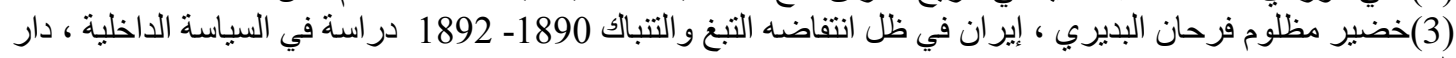

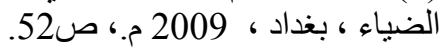

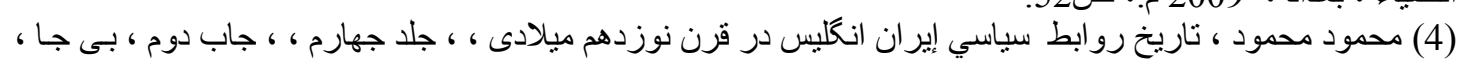

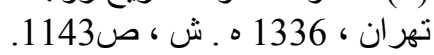
(5) خليل ابر اهيم صالح المشهاني ، العلاقات البريطانية الإير انية 1857-1907 ، دار ومكتبة عدنان ، بغداد ، 2015م.، ص الم 187.00

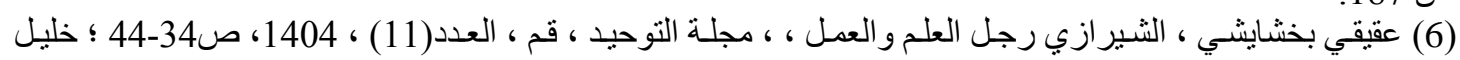

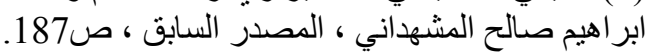

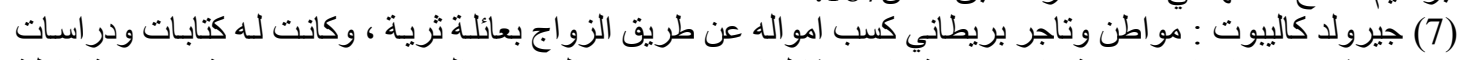

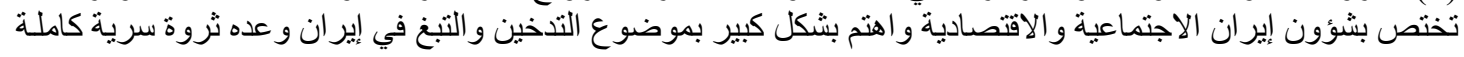




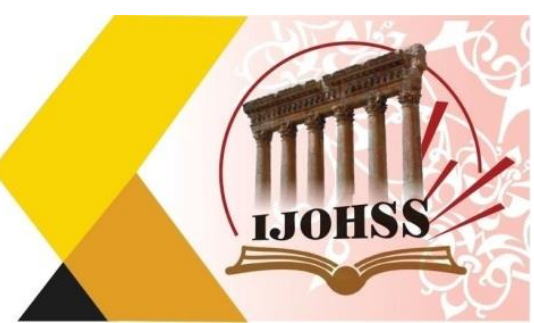

يمكن استغلالها الذي يفوق التبغ الهندي و العثماني لما يحمل من خصائص عطرية مميزة ـ للمزيد ينظر : خان ملك ساسـاني

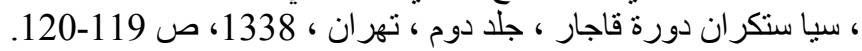

(4) Nikke R. Keddie, Religion and Rebellion in Iran,Tobacco Protest of 1891-1892, London ,1966,P.9.

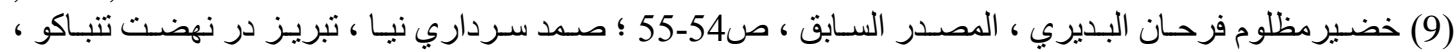

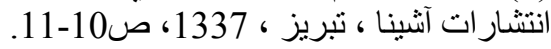

(10)علي خضير عباس المشايخي ، إيران في عهد ناصر الدين شاد التئ عام 1848 - 1896 رساله ماجستير غير منشوره ،

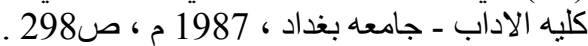

(11) نـاظم الاسلام كرماني ، تـاريخ بيدارى إير انيان بـان تاريخ مشروح وحقيقى مشروطيت إيران ، جلد اول ، مؤسسـة

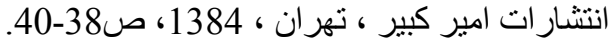

(12) محمد رضا زنجاني ، تحريم تتباكو ، مؤسسة انتثار فر اهاني ، تهران ، 1359، ص45 ؛ صمد سردارى نيا ، منبع

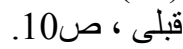

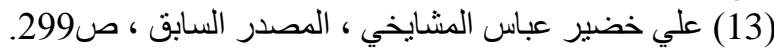

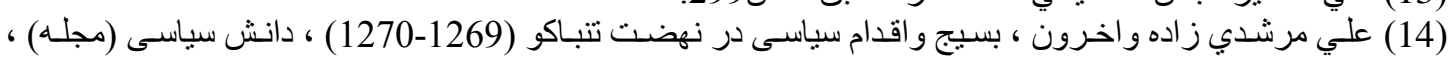

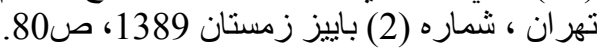

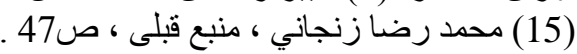

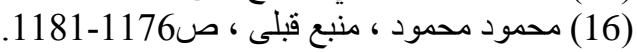

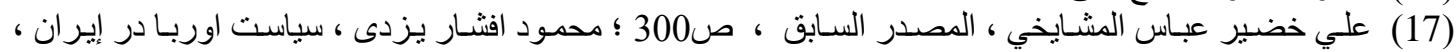

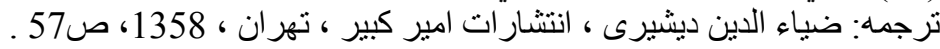

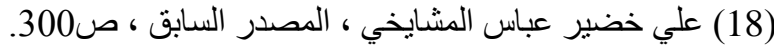

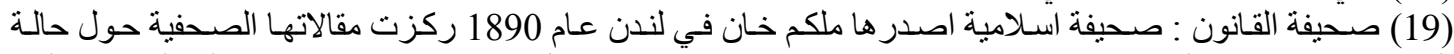

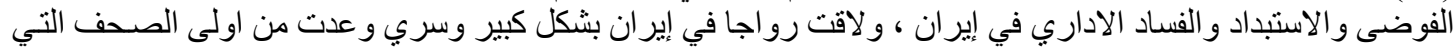

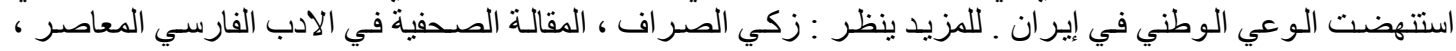

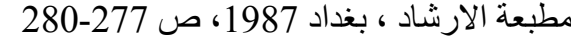

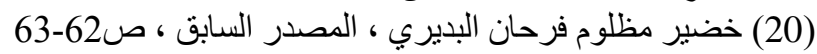

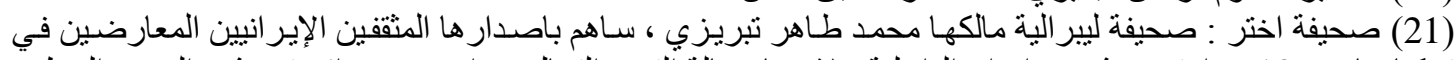

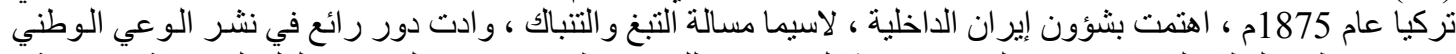

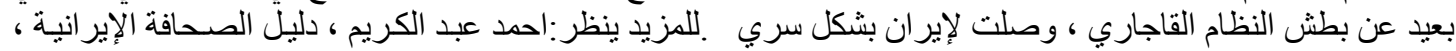

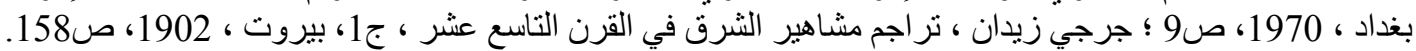

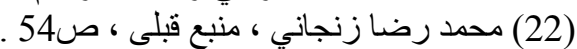
(23) عقيقي بخشايثـي ، كفاح علماء الاسـلام في القرن العشرين ، منشور ات مؤسسة الاعلمي للمطبو عات ، بيروت ،

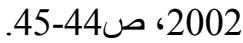

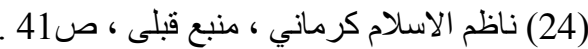

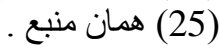

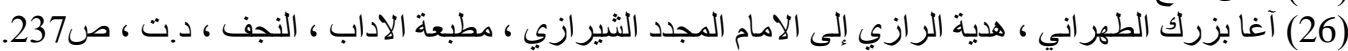

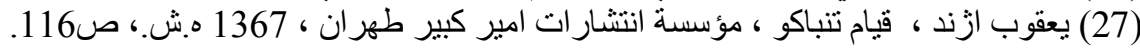

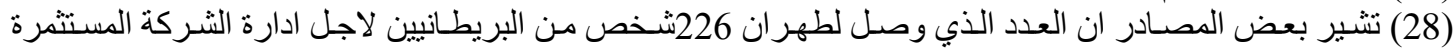

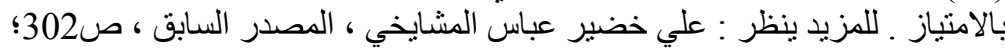
Avery P. and Simon J . Persia on Cross of Silver 1880-1890, in :Towards A Modern Iran , Studies in Thought, Politics and Society, Frank Cass , 1978 , P.25.

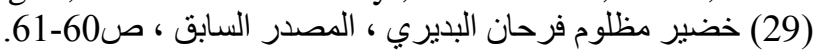

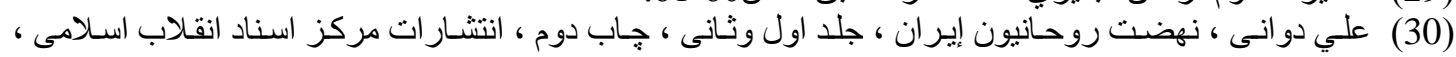

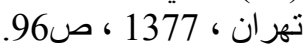
(31) ابر اهيم تيموري ، تحريم تتباكو اولين مقاومت منفى در إيران ، ج3، انتشار ات كتابهاى جيبى ، تهران ، 1361 هـش

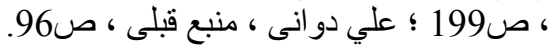
(32) ابو قاسم ظاهرى ، تاريخ روابط بازركانى وسياسى إيران و انكليس ، جلد دوم ، انتشار ات انجمن اثار ملى ، تهران

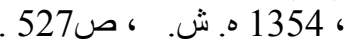




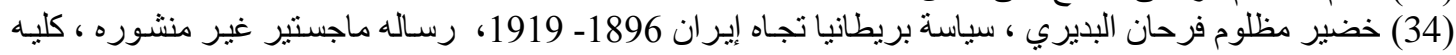

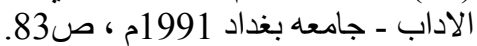

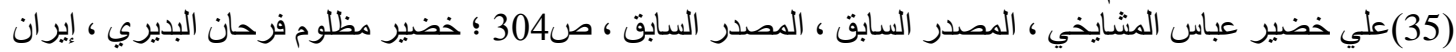

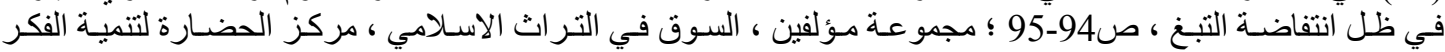

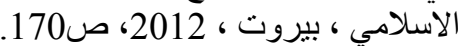

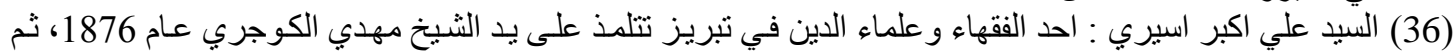

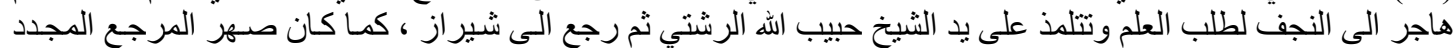

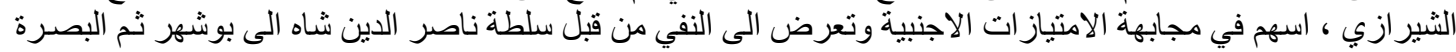

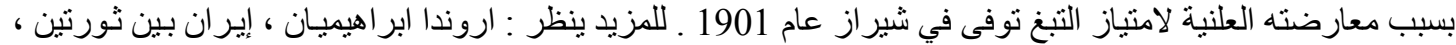

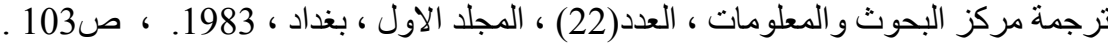

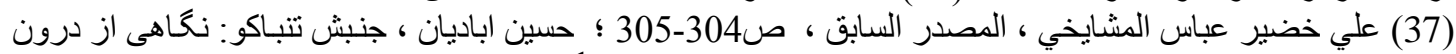

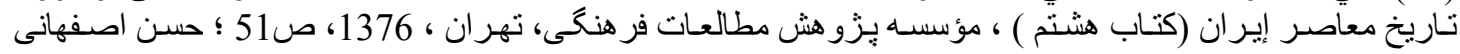

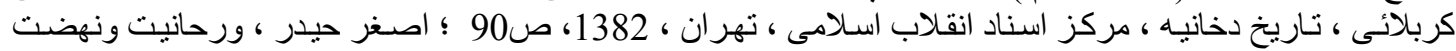

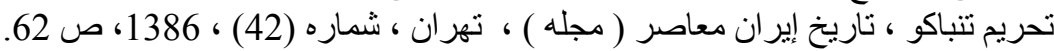

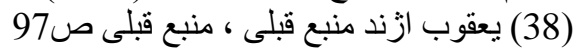

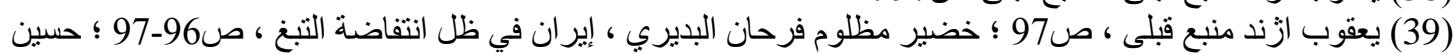

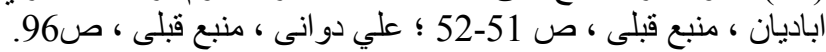

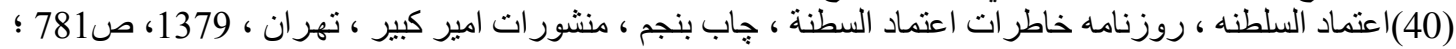

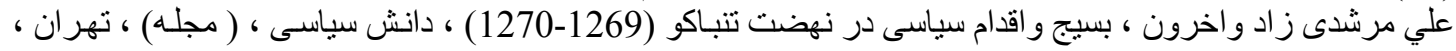

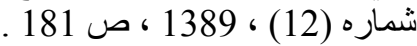
(41) علي خضير عباس المشايخي_، إيران في عهد ناصر الدين شـاه ، ص309؛ نـاظم الاسلام كرماني ، منبع قبلى ،

(42) خضير مظلوم فرحان البديري ، إيران في ظل انتفاضة التبغ ، ص989؛ حسين اباديان ، منبع قبلى ، ص53. (43) Algar. H. Algar H.,Religion and State in Iran 1785-1906 ,Los Angless ,1969 ,P . 209 .

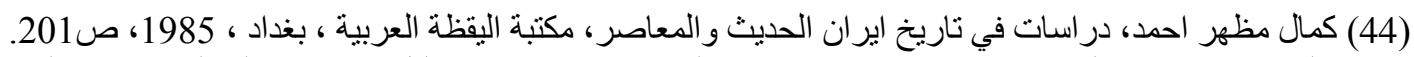

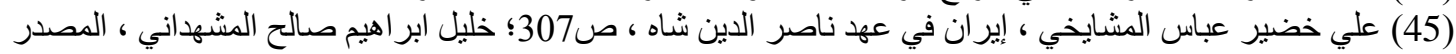

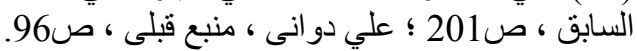

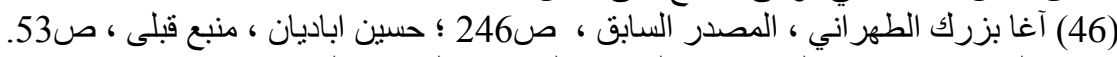

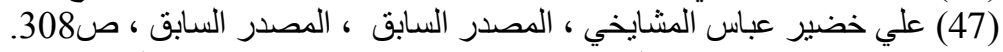

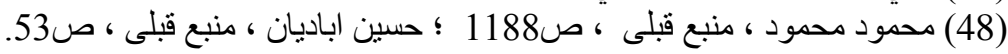

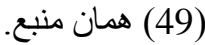

(50) الثيخ محمد آغا نجفي : هو محمد تقي بن محمد باقر آغا النجفي الأصفهاني الرازي، ولان عام

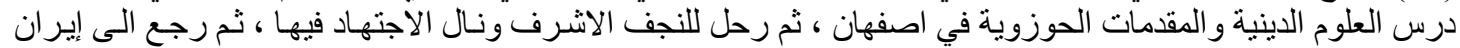

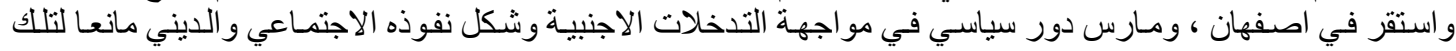

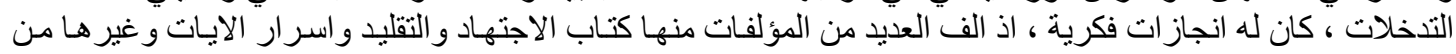

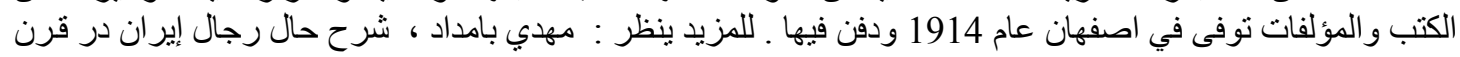

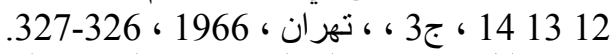

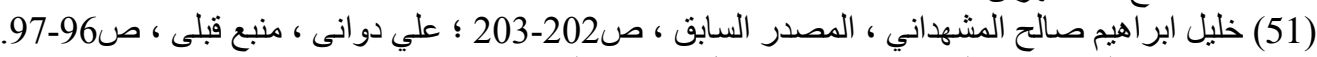

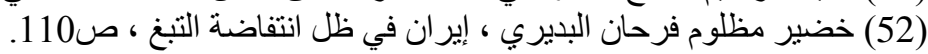

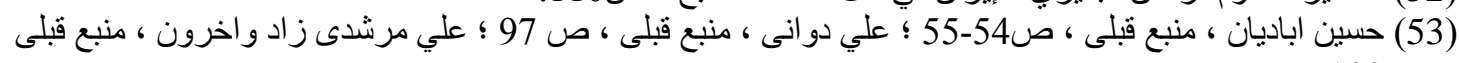

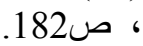

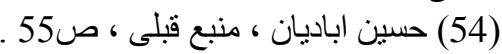

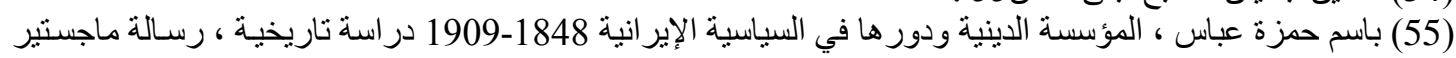

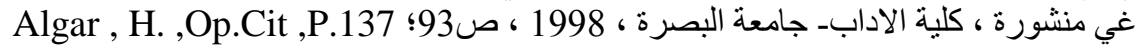

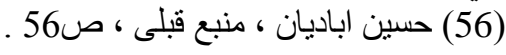




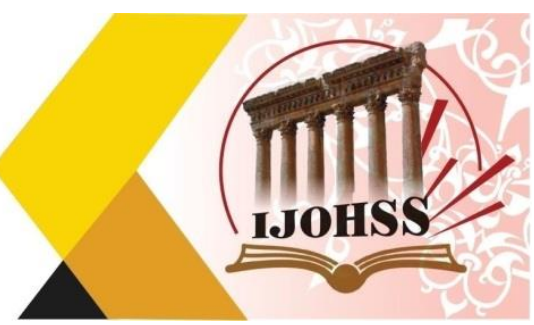

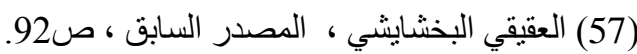

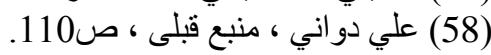

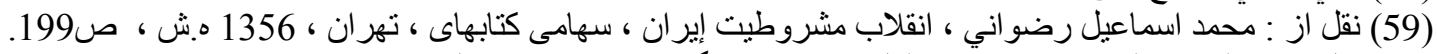

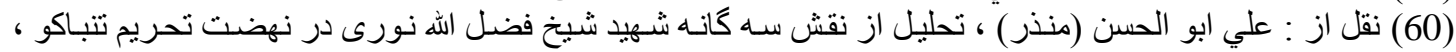

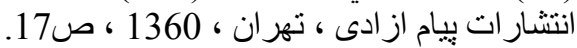

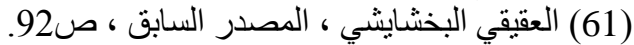

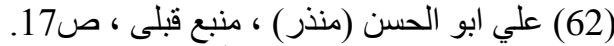

(63)مصطفى بروجردى ، فريادكر مشرو عة در بيداد مشروطه ، دفتر انتشار ات اسلامى ، قم ، 1362 ه ش ش. ص14.

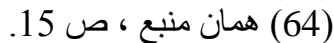

(65) خضبر مظلوم فرحان البديري ، إيران في ظل انتفاضه التبغ و التنباك ، ص114.

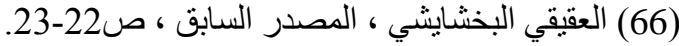

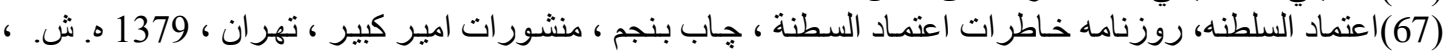

صا781)

(68) ميرز ا محمود خـان احتشـام السلطنه ، خـاطر ات احتشـام السلطنه ، جـاب بنجم ، انتشـار ات زوّار ، تهر ان ، 1367،

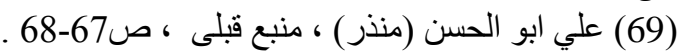

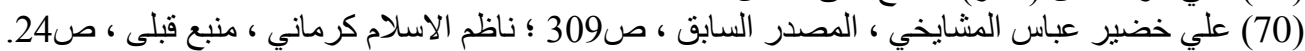

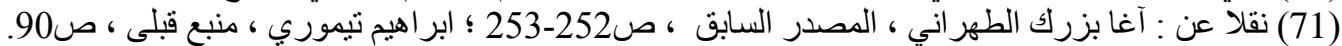

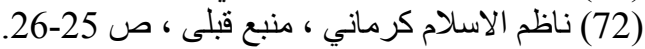

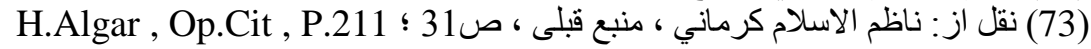

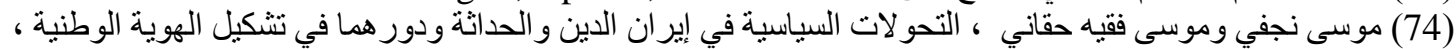

مؤسسة مطالعات تاريخ معاصر إيران ، بيروت ،

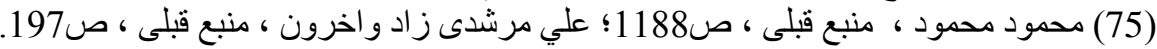

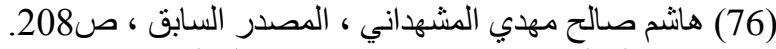

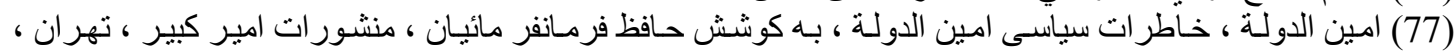

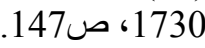

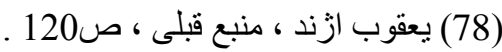

(79) نقل از : نكي ار كدي ، تحريم تنباكو در إيران ، جـاب دوم ، شركت سهامى متاب هاى جيبى ، تهران ، 1358،

(80) نقل از : حسن اصفهانى كربلائى ، تاريخ دخانيه ، مركز اسناد انقلاب اسلامى ، تهران ، 1382 ه. ش، ص 142.

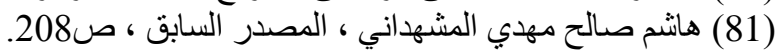

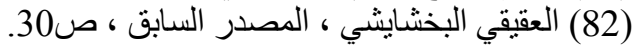

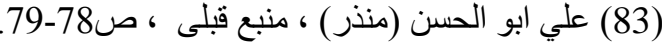

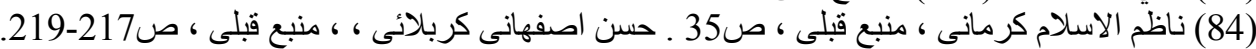

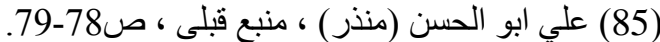

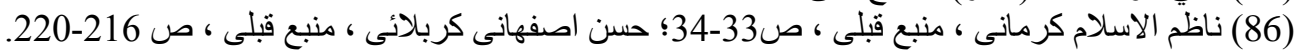

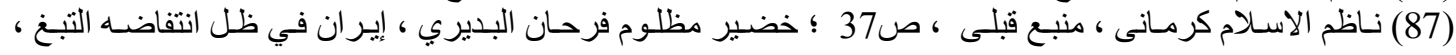

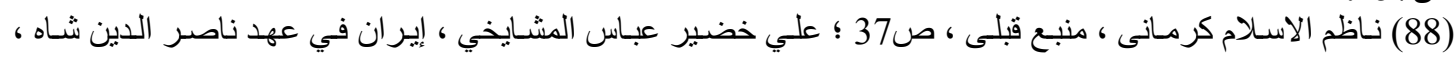

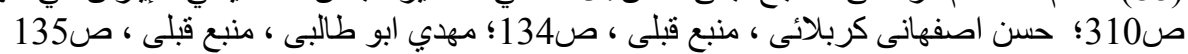

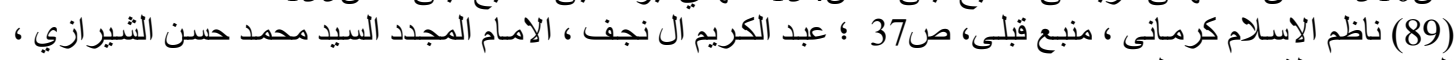

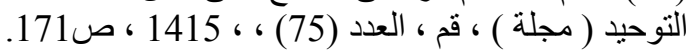

Algar. H. ,Op,Cit ,P 213 (90) علي خضير عباس المشايخي ، المصدر السابق ، ص310 ؛

$$
\begin{aligned}
& \text { (92) علي مرشدي ز اده و اخرون ، منبع قبلى ، ص201 ، } 201 .
\end{aligned}
$$

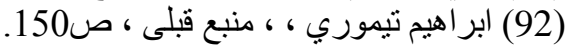

(93) Brown E .G ,T The Persian Revolution of 1905-1909, London ,1966 , P. 


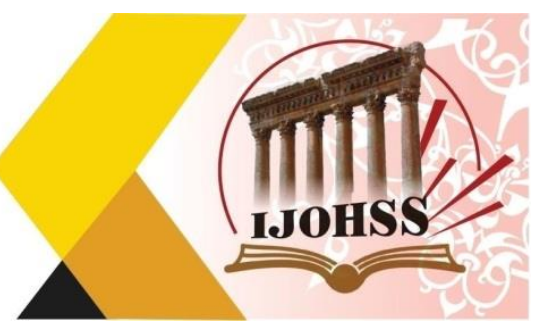

(94) Algar. H. ,Op,Cit ,P. 214.

(95) فيصل عبد الجبار عبد علي ، التاريخ السياسي للمؤسسة الدينية في إيران ، رسـالة ماجستير غير منشورة ، معهد

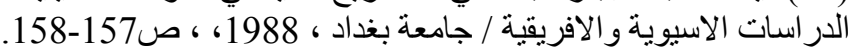

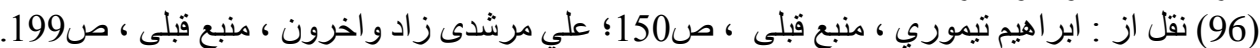

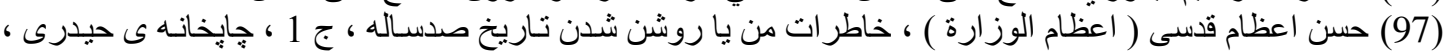

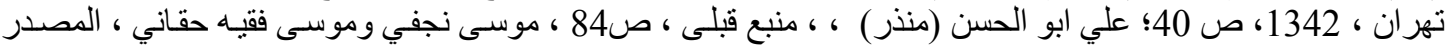

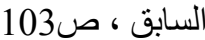

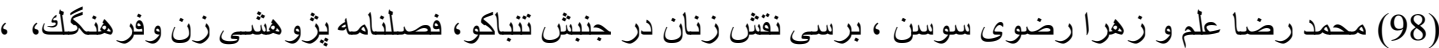

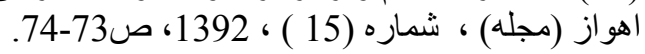

(100) Browne E.G., Op.Cit ,P.54

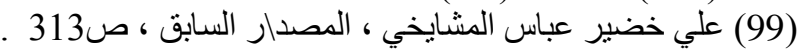

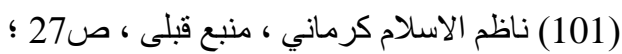

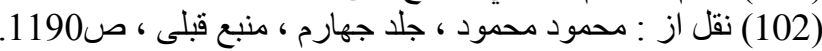

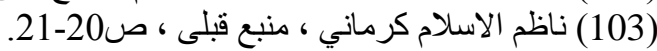

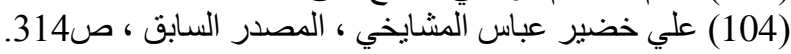

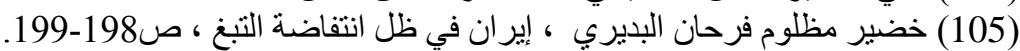 \\ (106) علي خضير عباس المشايخي ، المصدر السبابق ، ص314.
}

\title{
المصادر
}

1. ابر اهيم تيموري ، تحريم تتباكو اولين مقاومت منفى در إيران ، ج3، انتتــار ات كتابهاى جيبى ، تهران ،

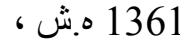
2. ابو قاسم طاهرى ، تاريخ رو ابط بازركانى وسياسى إيران وانكليس ، جلد دوم ، انتشار ات انجمن اثنار ملى ،

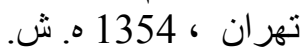

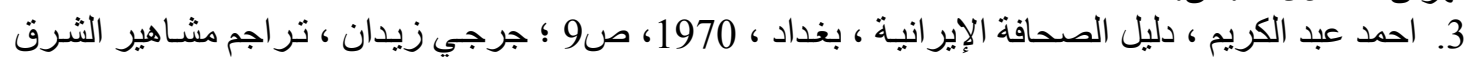

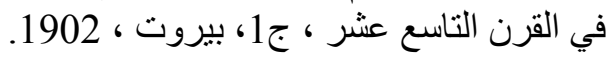

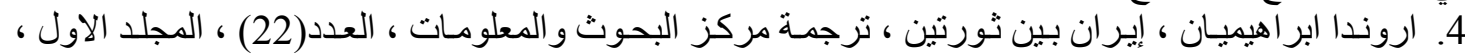

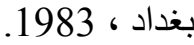
5. اصغر حيدر ، ورحانيت ونهضت تحريم تتباكو ، تناريخ إيران معاصر ( مجله ) ، تهران ، شماره (42) ، .1386

6. اعتماد السلطنه ، روزنامه خاطر ات اعتماد السطنة ، جاب بنجم ، منشور ات اتمبر كبير ، تهران ، 1379 ، 1379. 7.

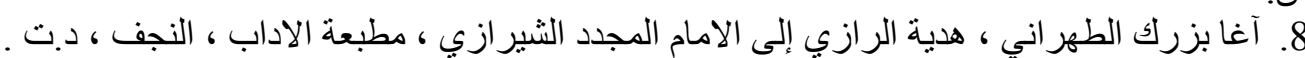

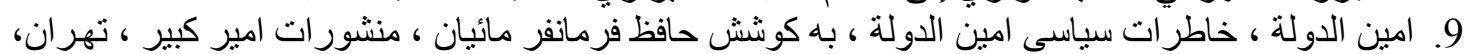

10. باسم حمزة عباس ، المؤسسة الدينية ودور ها في السياسية الإير انية 1848-1909 در اسـة تاريخية ، رسـالة

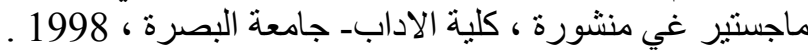

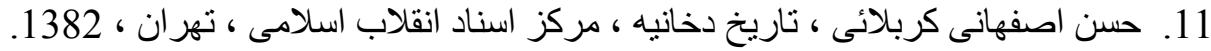

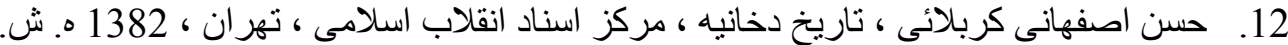

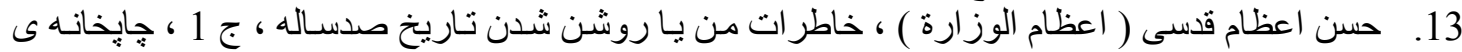

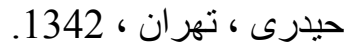




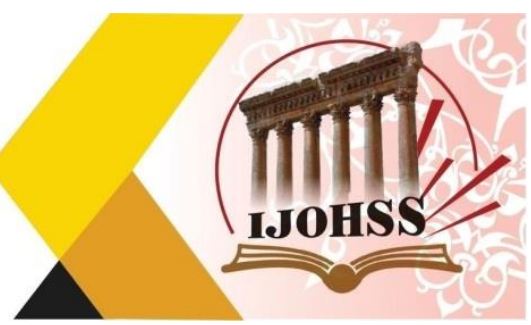

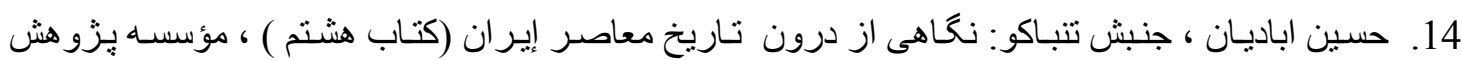

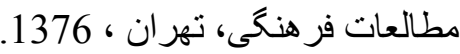

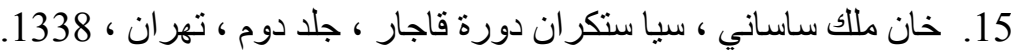

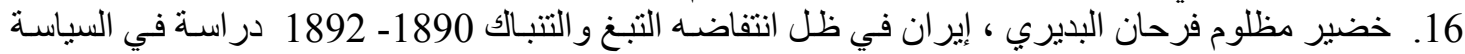

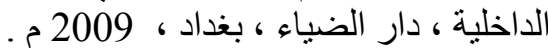
17. خضير مظلوم فرحان البديري ، سياسة بريطانيا تجاه إيران 1896- 1919 1919، رساله ماجستير غير منشوره

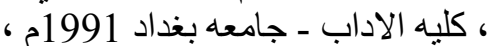

18. خليل ابر اهيم صالح المشهداني ، العلاقات البريطانية الإيرانية 1857-1907 ، دار ومكتبة عدنان ، بغداد ،

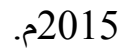

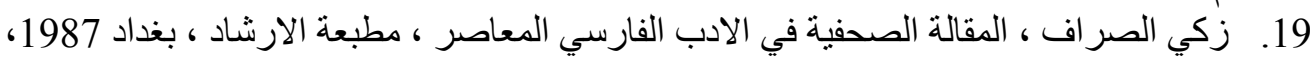

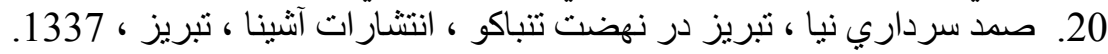

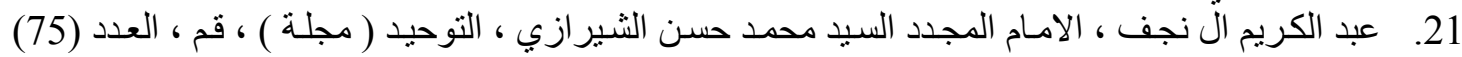
.1415 ،

22. عقيقي بخشايشي ، الثيرازي رجل العلم و العمل ، ، مجلة التوحيد ، قم ، العدد(11) ، 1404.

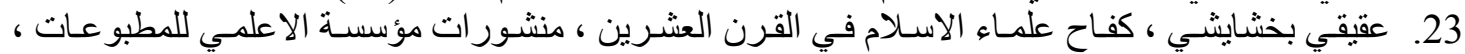

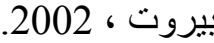

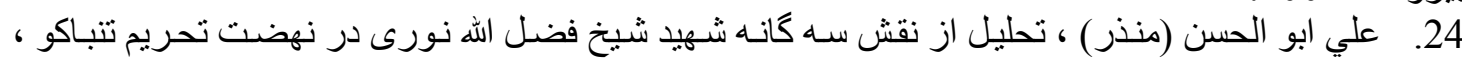

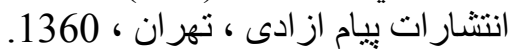

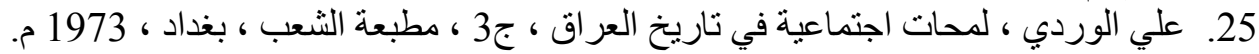

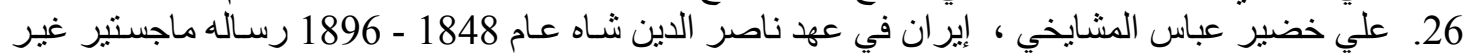
منشوره ، كليه الاداب - جامعه بغداد ، 1987 ، 1987 م.

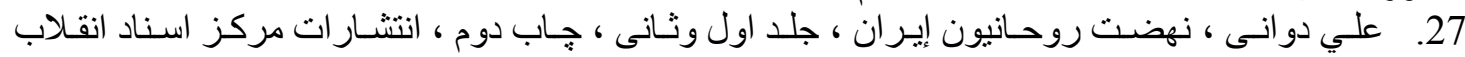

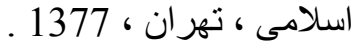

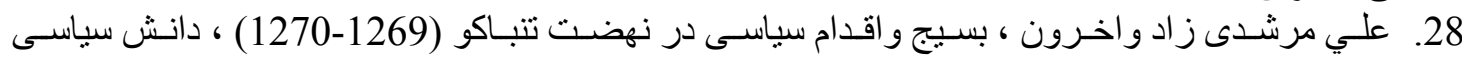

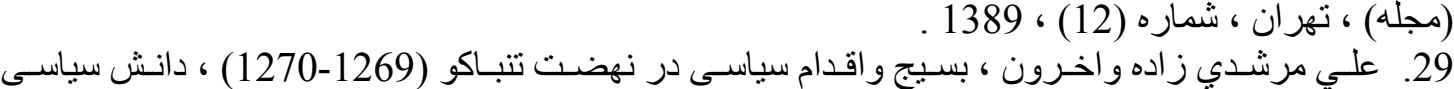

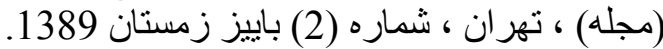

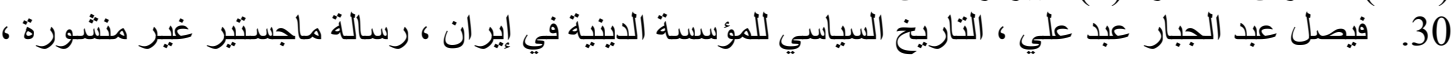

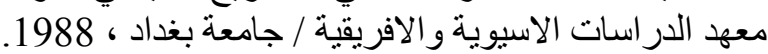

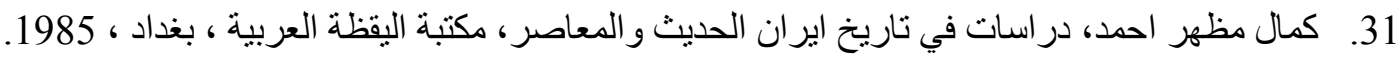

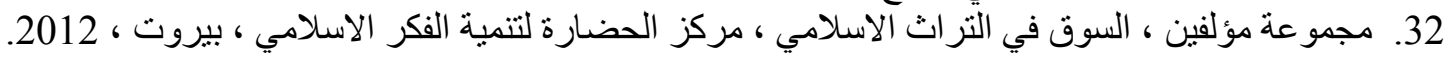

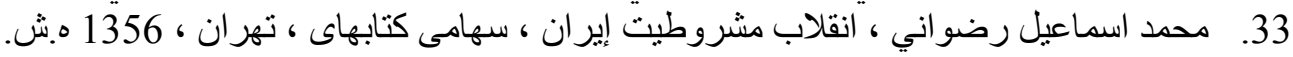

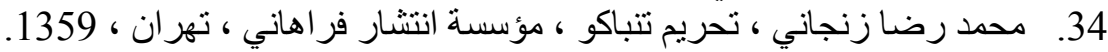

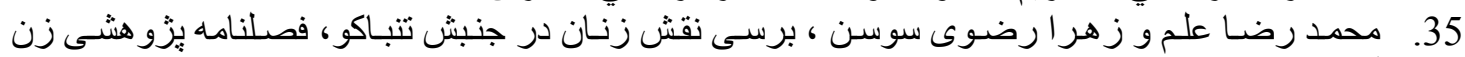

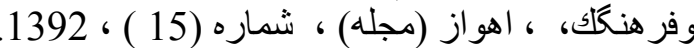

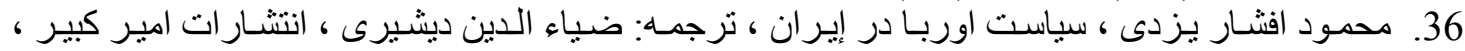

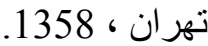
37. محمود محمود ، تاريخ رو ابط سياسي إيران انكليس در قرن نوزدهم ميلادى ، ، جلد جهارم ، ، ، جاب دوم

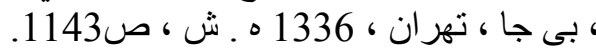

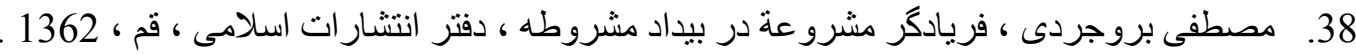

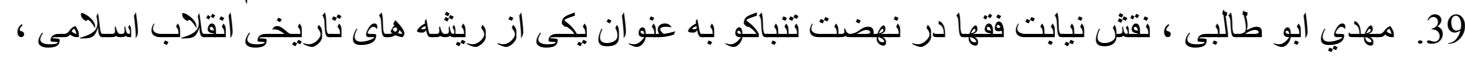
مطالعات انقلاب اسلامى ( مجله ) ) ، تهران ، شماره (

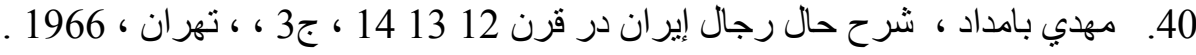




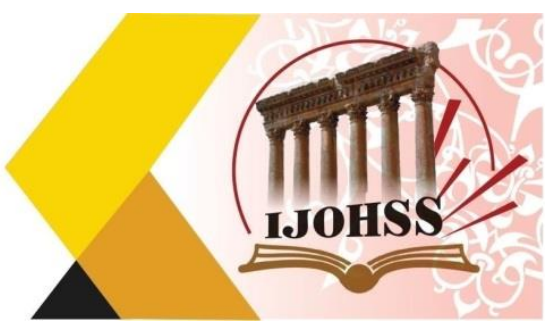

41. موسى نجفي وموسى فقيه حقاني ، التحو لات السياسية في إيران الدين والحداثة ودور هما في تثكيل الهويـة

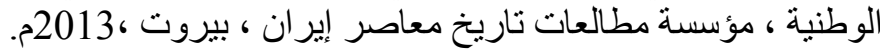

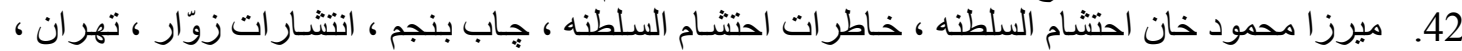

43. ناظم الاسلام كرماني ، تناريخ بيدارى إير انيان بـا تاريخ مشروح وحقيقى مشروطيت إيران ، جلد اول ،

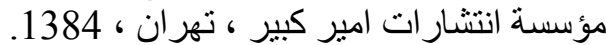

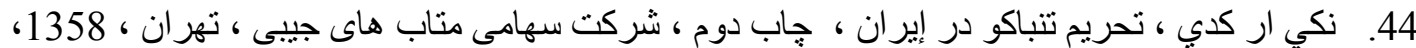

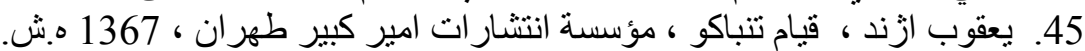

46. Algar. H. Algar H.,Religion and State in Iran 1785-1906 ,Los Angless ,1969.

47. Avery P. and Simon J . Persia on Cross of Silver 1880-1890, in :Towards A Modern Iran, Studies in Thought, Politics and Society, Frank Cass, 1978.

48. Brown E .G ,T The Persian Revolution of 1905-1909, London ,1966 .

49. Nikke R. Keddie, Religion and Rebellion in Iran,Tobacco Protest of 18911892, London ,1966 . 